\title{
Ontogeny and functional histochemistry of the digestive and visual systems and other organs during the larval development of the thick-lipped grey mullet, Chelon labrosus
}

\author{
Carmen Sarasquete ${ }^{1}$, Juan B. Ortiz-Delgado ${ }^{1}$, J. Antonio Martos-Sitcha ${ }^{1}$, \\ Verónica de las Heras ${ }^{1,2}$, Manuel Yúfera ${ }^{1}$, Gonzalo Martínez-Rodríguez ${ }^{1}$ \\ ${ }^{1}$ Instituto de Ciencias Marinas de Andalucía (ICMAN-CSIC). Campus Universitario Río San Pedro. Apdo Oficial, 11510, \\ Puerto Real, Cádiz, Spain. E-mail: carmen.sarasquete@icman.csic.es \\ ${ }^{2}$ Futuna Blue España S.L. El Puerto de Santa María, Cádiz, Spain.
}

\begin{abstract}
Summary: The main ontogenetic and functional changes of the digestive and visual systems of Chelon labrosus during the first three months from fertilization until 99 days post-hatch (dph) are described. An extended slow growth pattern (3.93\%) during the first three weeks of larval life was discernible. A long transitional period of mixed endo-exogenous feeding was noticeable until $13 \mathrm{dph}$. The majority of organ systems and structures (eye, digestive system, liver, pancreas, thyroid and others) were developed and functional before first feeding (mouth opening at $4 \mathrm{dph}$ ). First differentiation of gastric glands was detected at $16 \mathrm{dph}$, with the appearance of a noticeable pyloric muscular portion or typical gizzard and first developed pyloric caeca from $23 \mathrm{dph}$. The presence of pinocytotic supranuclear vesicles $(5 \mathrm{dph})$ was still visible in the posterior intestine until the third month of life. The eyes exhibited early differentiation and functionality (pigmentation, first cone-type photoreceptors) during the lecithotrophic phase ( $2 \mathrm{dph})$, and development of all typical retinal layers containing different retinal cell types was progressively discernible from $16 \mathrm{dph}$ onwards. From this time, rod photoreceptor precursor cells were incorporated into the basal region of the outer nuclear layer, and increases of two types of photoreceptors (cones and rods) were detected from $23 \mathrm{dph}$.
\end{abstract}

Keywords: thick-lipped grey mullet; Chelon labrosus; embryo; larva; growth; yolk; ontogeny; digestive, vision; histochemistry.

Ontogenia e histoquímica funcional de los sistemas digestivo y visual y de otros órganos durante el desarrollo larvario de la liseta, Chelon labrosus.

Resumen: El objetivo del trabajo se centró en describir los principales cambios ontogénicos y funcionales de los sistemas digestivo y visual de Chelon labrosus, durante los primeros tres meses de vida larvaria, desde la fertilización hasta 99 dias después de eclosionar (dde). Se observó un largo periodo de reducido crecimiento (3.93\%) durante las tres primeras semanas de vida, y una amplia fase de alimentación endo-exotrófica (hasta 13 dde). La mayoría de sistemas, órganos y estructuras tisulares (ojo, digestivo, hígado, páncreas, tiroides, entre otros) se evidenciaron desarrollados y funcionales antes de iniciarse la primera alimentación (apertura de la boca a los 4 dde). Las glándulas gástricas se desarrollaron a partir de 16 dde y la porción pilórica muscular o típica molleja y los ciegos pilóricos eran visibles a los 23 dde. La presencia de vesículas proteicas supranucleares pinocitóticas era evidente en el intestino posterior ( 5 dde $)$ y hasta el tercer mes de vida. Los ojos presentaron una precoz diferenciación y funcionalidad (pigmentación, fotorreceptores tipo conos) durante la fase lecitotrófica ( 2 dde) y se observó un desarrollo progresivo de todas las capas retinales, y conteniendo los diferentes tipos celulares desde los 16 dde. A partir de este periodo, algunos precursores de fotorreceptores tipo bastones se incorporaron en la región basal de la capa nuclear externa, y a partir de 23 dde se evidenció una proliferación de ambos tipos de fotorreceptores -conos y bastones-.

Palabras clave: liseta; Chelon labrosus; embrión; larva; crecimiento; vitelo; ontogenia; digestivo; visión; histoquímica.

Citation/Como citar este artículo: Sarasquete C., Ortiz-Delgado J.B., Martos-Sitcha J.A., de las Heras V., Yúfera M., Martínez-Rodríguez G. 2014. Ontogeny and functional histochemistry of the digestive and visual systems and other organs during the larval development of the thick-lipped grey mullet, Chelon labrosus. Sci. Mar. 78(4): 473-491. doi: http://dx.doi. org/10.3989/scimar.04091.27B

Editor: J.J. Govoni.

Received: May 15, 2014. Accepted: October 14, 2014. Published: November 27, 2014.

Copyright: (c) 2014 CSIC. This is an open-access article distributed under the Creative Commons Attribution-Non Commercial Lisence (by-nc) Spain 3.0. 


\section{INTRODUCTION}

The thick-lipped grey mullet, Chelon labrosus (Mugilidae) is a euryhaline teleost common in estuaries, coastal lagoons, intertidal marshes and earth ponds in the northeastern Atlantic and Mediterranean coasts. This species, together with other mullets, is currently of local importance in extensive aquaculture in some of these habitats (Drake et al. 1984, Arias and Drake 1990, Yúfera and Arias 2010). Its reproduction takes place during winter and eggs and larvae are pelagic. In coastal environments, during the recruitment phase, both larval (planktivorous) and adult (grazing or detritivorous) feeding strategies coexist in relative proportions, changing according to the food type availability. Mullets have a characteristic gizzard or gastric mill that is a specialized pyloric stomach formed by thick, muscular walls used for grinding up food, and to aid in digestion of detritus, sediments, waste nutrients and other residues (Albertini-Berhaut 1973, Bruslé 1981a,b, Drake et al. 1984).

One of the most noteworthy ecological features is that mullets are an important component in the energy flow through the ecosystem, because they are on the lowest trophic level of the fish food chain, utilizing plants and vegetal detritus as an energy source. The production of Mugilidae may be carried out in a variety of ecosystems, such as lagoons and freshwater reservoirs and ponds, or even as supplementary crops of carp ponds (Cataudella et al. 1988, Eda et al. 1990, Boglioni et al. 1992, Crosetti and Cataudella 1995, Besbes et al. 2010). Traditional extensive culture systems, departing from captured wild fry, have been described as the most efficient and economic way of producing mullets (Arias and Drake 1990, Yúfera and Arias 2010). Chelon labrosus is an interesting species to diversify aquaculture, and the success of sustainable productions of the Mugilidae could also be a result of their reproductive strategies, food preferences and feeding behaviours (Albertini-Berhaut 1973, Bruslé 1981a,b, Drake et al. 1984, Crosetti and Cataudella 1995, Ben Khemis et al. 2006, 2013).

In most altricial fish larvae, the development of many biological and ecologically important features, including senso-visual organs, the digestive system, the skeleton, external pigmentation of fins and other structures, occurs gradually and over a large portion of the larval period. At hatching, the visual system is non-functional, because the eyes are formed but they lack pigment and photoreceptors (Blaxter and Staines 1970, Blaxter 1975, 1986, Evans and Browman 2004). Likewise, jaws and gills are not developed yet, the mouth and anus are poorly structured and locomotion control is limited (Falk-Petersen 2005). At the onset of the exogenous feeding period, fish larvae are mostly visual feeders, indicating that vision plays an important role in larval orientation during this early larval developmental stage. The ontogeny of different organ systems involved in the capture and digestion of food is basically similar among teleosts, and both the feeding and sense systems develop very early during larval life (Blaxter 1986, Govoni et al. 1986, Hubbs and Blaxter 1986, Huse 1993). Nevertheless, the existence of significant species-specific differences related to variable biotic and abiotic factors (i.e. feeding behaviour, climate range, temperature, and others), which are related to sequential timing of appearance and complete functionality of different organ systems and tissues, makes it necessary to study each single species separately. Consequently, the use of histological and histochemical approaches during larval fish ontogeny (Sarasquete 1993a,b, 1995, 1996, Segner et al. 1994, Ortiz-Delgado et al. 2003, 2006, 2012) may aid the identification of growth patterns and larval critical periods. Several biochemical, physiological and cellular biomarkers can also provide information for the monitoring and optimization of rearing technologies, optimal feeding protocols, nutritional requirements and feeding behaviours (Govoni et al. 1986, Gisbert et al. 2008, Zambonino-Infante et al. 2008, Hamre et al. 2013, Pittman et al. 2013, Rønnestad et al 2013) in order to achieve the best improvements for increasing the efficiency in a sustainable fish production (i.e. optimal growth and survival and reduced costs).

The aim of the present study was to describe the ontogenetic and functional changes during the first months of embryonic and larval life of the reared thicklipped grey mullet, C. labrosus, using histological and histochemical approaches. Particularly, we coupled larval growth with yolk sac and oil globule resorption and described the differentiation, development and functionality of the digestive tract and visual systems. We also analysed the functional organogenesis of other different vital target organs and tissues required to allow an optimal development and growth of this typical omnivorous-detritivorous mullet species when larvae were reared under standardized zootechnical intensive conditions.

\section{MATERIALS AND METHODS}

\section{Experimental procedures and rearing conditions}

Fertilized eggs of $C$. labrosus were obtained from natural spawning in captivity from IES Els Alfacs (Sant Carles de la Rápita, Tarragona, Spain) and transferred to the Instituto de Ciencias Marinas de Andalucía (ICMAN-CSIC (Experimental Animal Facilities Register number ES110280000311, Puerto Real, Cádiz, Spain). Larvae were reared in 150-L conical tanks from hatching ( 0 days post-hatching [dph]) to $3 \mathrm{dph}$, after which they were transferred to 250 -L flat-bottom tanks until the end of the experiment ( $99 \mathrm{dph}$ ). Larvae were reared under a photoperiod of $12 \mathrm{~h}$ light and $12 \mathrm{~h}$ dark. The oxygen concentration ranged between 7.5 and $8.5 \mathrm{mg}$ $\mathrm{L}^{-1}$ and $\mathrm{pH}$ between 7.6 and 7.9, with constant water temperature $\left(18-19^{\circ} \mathrm{C}\right)$ and salinity $(35 \mathrm{ppt})$. After mouth opening ( $4 \mathrm{dph})$, larvae were fed rotifers (Brachionus plicatilis) at a density of 5 prey $\mathrm{mL}^{-1}$. Artemia sp. nauplii (0.3-0.5 prey $\mathrm{mL}^{-1}$; Ben Khemis et al., 2006) were supplied from $6 \mathrm{dph}$, which was gradually replaced with enriched meta-nauplii between 13 and 25 dph (1 prey $\left.\mathrm{mL}^{-1}\right)$ and $0.1,0.2$ and $0.5 \mathrm{~mm}$ commercial diets ad libitum (Skretting, Burgos, Spain) which were the only food offered to larvae from $25 \mathrm{dph}$ onwards. 


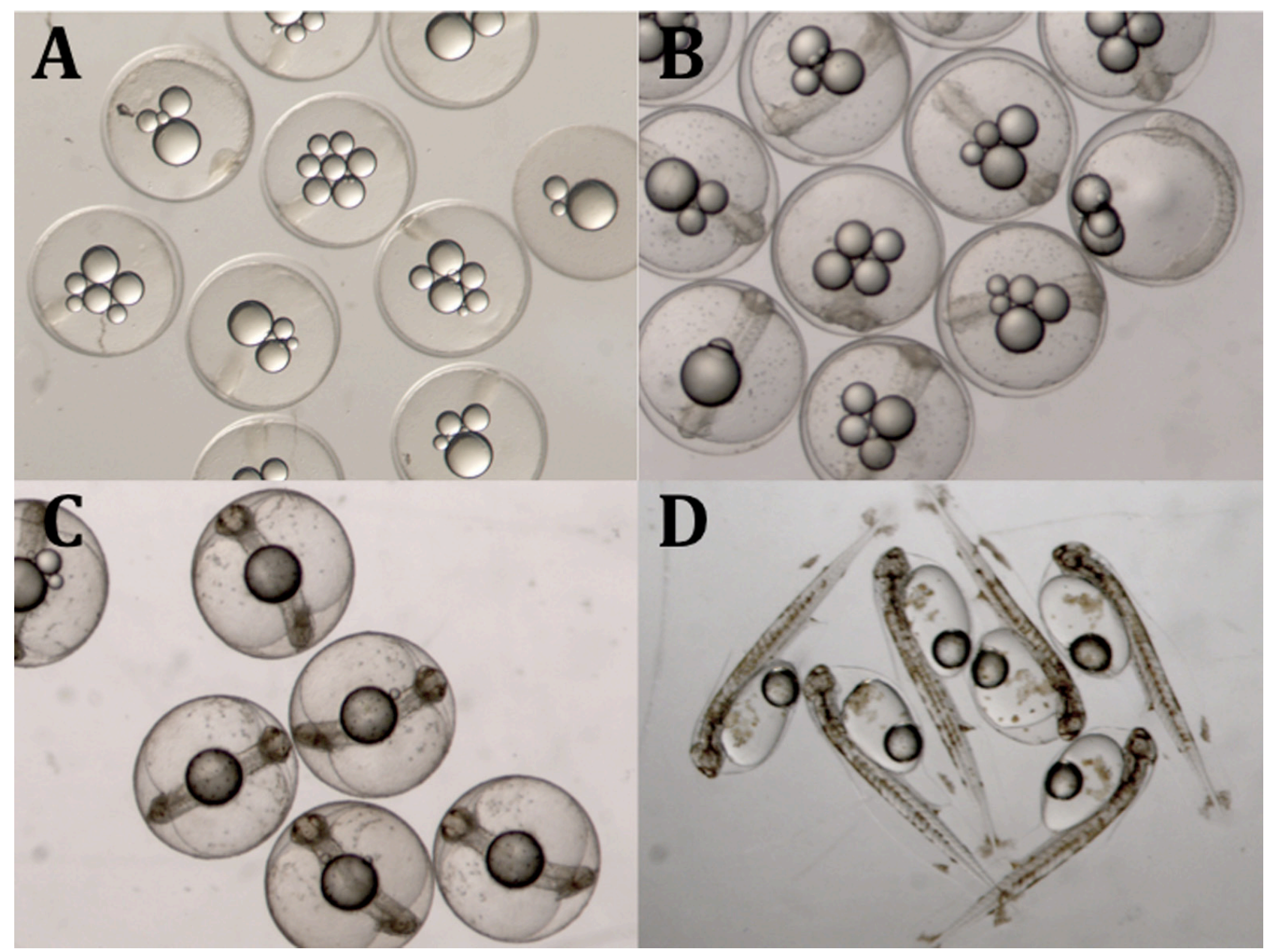

Fig. 1. - Presence and utilization of oil globules in eggs (A to C) and larvae (D) of the Chelon labrosus. A, 24 hours after fertilization (haf); $\mathrm{B}, 32$ haf; C, 48 haf; D, 2 hours post-hatching (hph). Scale bars $1.0 \mathrm{~mm}$.

\section{Yolk resorption and larval growth}

For total length (TL) and weight (0 to $99 \mathrm{dph}$ ) measurements, 10-30 larvae, depending on the size and days after hatching (dph), were caught every two, four or seven days, anesthetized with benzocaine $\left(1 \mathrm{~g} \mathrm{~L}^{-1}\right)$ and washed with MilliQ water. Dry weight (DW) was measured by drying specimens in an oven (P-Selecta Mod. 203) at $70^{\circ} \mathrm{C}$ for 48 hours and weighing in a microbalance (Mettler Toledo mod. XP2U). Growth rate was taken as $\mathrm{b}$ (\% of weight increase) in the growth curve $\mathrm{DW}=\mathrm{a} \mathrm{e}^{(\mathrm{bT})}$, where $\mathrm{a}$ is the constant parameter and $\mathrm{T}$ the time after hatching (dph). Yolk and oil globule volume $(\mathrm{V})$ was calculated by image analysis (Image $J$ software) according to the formula $V=4 / 3 \pi a b^{2}$, where $a$ is the larger radius and $b$ the smaller radius.

\section{Statistical analysis}

The three different periods $(\mathrm{A}, \mathrm{B}, \mathrm{C})$ described were assessed by observing the path length and weight values with respect to the age. For each period, the best linear regression model on log-transformed data was obtained by least-squares fitting. Slopes of regression models were used as an estimation of corresponding growth rates. Differences in growth performances dur- ing rearing were tested by comparing (Student t-tests) the regression line slopes of the three growth periods. All tests were performed using GraphPad Prism (v $5.0 \mathrm{~b})$ software. Statistically significant differences were defined at $\mathrm{P}<0.05$.

\section{Histological and histochemical analysis}

Samples for the histological analysis were taken every $2 \mathrm{~d}$ from hatching $(0 \mathrm{dph})$ until day 78 . Larvae were fixed in $4 \% \mathrm{v} / \mathrm{v}$ buffered formaldehyde (pH 7.2) and embedded in paraffin blocks. Sagittal and transversal histological sections of 5-7 $\mu \mathrm{m}$ thickness from whole specimens were stained with haematoxylin-eosin (H-E) and haematoxylin-VOF (VOF: light green-orange G-acid fuchsin) according to Sarasquete and Gutiérrez (2005). Histochemical techniques and methods: PAS, diastase-PAS, Alcian Blue $\mathrm{pH}$ 0.5, 1 and 2.5 (glycogen, neutral and acidic glycoconjugates), bromophenol blue (general proteins) and specific techniques to detect proteins rich in amino acids (lysine, tyrosine, arginine, tryptophan, arginine, cysteine and cystine) were performed according to general and standardized technical protocols for fish larvae (Pearse 1985, Sarasquete et al. 1995). In some larvae samples, a more specific detec- 


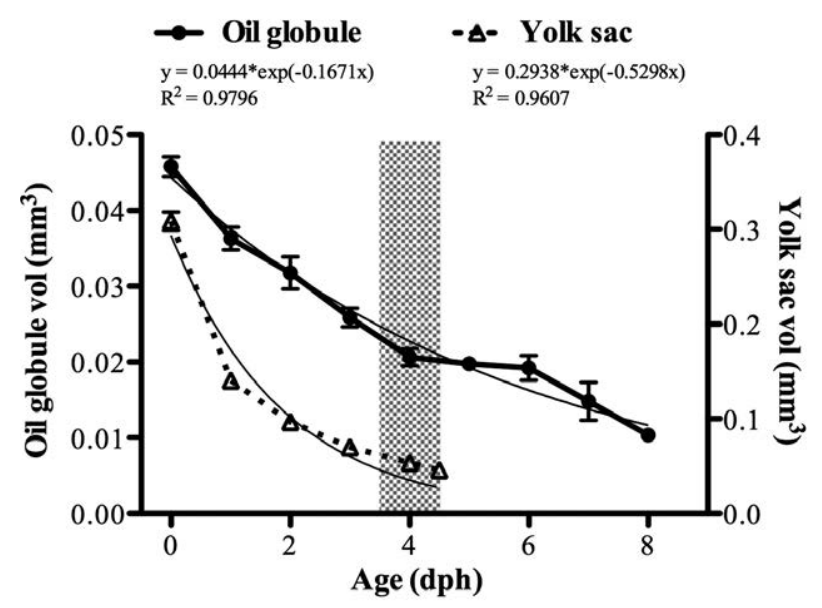

Fig. 2. - Oil globule and yolk sac reabsorption in Chelon labrosus larvae. Values are represented as mean \pm S.E.M $(n=25-30)$. Thin lines represent exponential regression plots. The equations were estimated taking into account individual larvae. Bar represents the time of mouth opening (4 days post-hatching, dph). tion of unsaturated neutral lipids (osmium tetroxide postfixation/lipid unsolubilization) was performed (Kiernan 1999).

\section{RESULTS}

\section{Yolk reabsorption and growth pattern}

The embryo developed as a blastodisc at the animal pole, and the periphery of the blastodisc overgrew the yolk enclosing it to form the gastrula at 5 hours post fertilization (hpf). The embryonic axis is completely formed in a boundary of the egg $24 \mathrm{hpf}$. A variable number of oil globules (between 3 and 7) were observed in the eggs, melting into a single drop at 48-72 hpf (Fig. 1). At hatching, the yolk sac contained a single vacuole corresponding to the oil globule (Fig. 1). Utilization of yolk (Fig. 2) showed pronounced absorption between $1 \mathrm{dph}$ and $4 \mathrm{dph}$ $\left(\mathrm{V}=0.2967 \exp ^{(-0.5569} \mathrm{T}\right)$, reaching approximately $78 \%$

Table 1. - Schematic synthesis of the main ontogenetic events occurring in Chelon labrosus larvae during the lecitotrophic (Stage 1) and endoexogenous (Stage 2) phases. Numbers in brackets indicate the age in days post-hatching (dph) Ai, anterior intestine; Bc, blood cells; Bphc, bucopharyngeal cavity; CC, chloride cells; Ep, exocrine pancreas; GaG, gas gland; Hc, hepatocytes; I, intestine; Li, liver; Mc, mucous cells; Md, mandibular; Oe, oesophagus; OG, oil globule; P, periblast; Ph, pharyngeal; Pi, posterior intestine; RtM, rete mirabile; Si, supranuclear inclusions; St, stomach; TB, taste buds; YS, yolk sac; YSL, yolk syncythial layer; Zg, zymogen granules.

\begin{tabular}{|c|c|c|}
\hline & Stage $1(0-4 \mathrm{dph})$ & Stage 2 (5-13 dph) \\
\hline Endogenous reserves & $\begin{array}{l}\text { Homogeneous acidophilic YS and OG surrounded } \\
\text { by periblast }(\mathrm{P}) \text { or YSL }(0) \text {. Initial yolk } \\
\text { fragmentation }(3-4) \text {. }\end{array}$ & Complete resorption of YS (8) and OG (12-13). \\
\hline Digestive system & $\begin{array}{l}\text { Mouth and anus closed. Straight and } \\
\text { undifferentiated gut tube (1). Bphc, Oe, anlage } \\
\text { St-gut and differentiated I (2-3). Opened anus and } \\
\text { mouth differentiated into movable jaws (4); Md and } \\
\text { Ph teeth present (4). Presence of intestinal valve } \\
\text { between } \mathrm{Ai} \text { and Pi (3-4). }\end{array}$ & $\begin{array}{l}\text { TB and Mc in Bphc (5). Elongation, appearance } \\
\text { of longitudinal folds, external circular muscular } \\
\text { layer and Mc in Oe (5-6). St develops and becomes } \\
\text { folded and thickening of mucosal layer in the } \\
\text { primordial St (5). Intestinal folds and loops evident } \\
(6) \text {. Mc seen in Ai and Pi (6). Appearance of } \\
\text { acidophilic protein Si within enterocytes of Pi (5) } \\
\text { and first signs of intestinal lipid absorption in Ai } \\
(8-9) \text {. }\end{array}$ \\
\hline Accessory glands & $\begin{array}{l}\text { Primordial liver and pancreas (1) as a mass of } \\
\text { undifferentiated basophilic cells. Hc and Ep } \\
\text { differentiated and appearing as a cord-like structure } \\
\text { between YS and gut (2-3). Hc packed between } \\
\text { sinusoids and showing glycogen, protein granules } \\
\text { and lipid vacuoles (4). Circulating Bc between } \\
\text { sinusoids (4). Acinar organization of the Ep and } \\
\text { accumulation of Zg (3). Gall bladder anlage visible } \\
\text { and formed by squamous epithelium (2-3). }\end{array}$ & $\begin{array}{l}\text { Opening of the choledochus and bile ducts into the } \\
\mathrm{Ai}(5-6) \text {, as seen with pancreatic ducts. Noticeable } \\
\text { increase in size of Li and Ep. }\end{array}$ \\
\hline Swim bladder & $\begin{array}{l}\text { Primordial swim bladder seen (2). Early } \\
\text { development of GaG and RtM (4). }\end{array}$ & Complete development of GaG and RtM (5). \\
\hline Eye & $\begin{array}{l}\text { Differentiation at hatching. Photoreceptor }(\mathrm{Cn}) \\
\text { differentiation (2). Pigmentation (2) and complete } \\
\text { development of retinal layers (2-3). }\end{array}$ & $\begin{array}{l}\text { Retinal thickening in the temporal area into an area } \\
\text { lateralis }(6) \text {. }\end{array}$ \\
\hline Gills & $\begin{array}{l}\text { Gill anlage visible from } 1 \text { dph onwards. } \\
\text { Chondrogenesis starting (3). Primordial gill } \\
\text { filaments (4). }\end{array}$ & $\begin{array}{l}\text { Appearance of CC (5-6). Filament, vascular } \\
\text { structures and gill lamellae differentiation }(8-10) \text {. }\end{array}$ \\
\hline Heart & $\begin{array}{l}\text { Pericardial cavity appearing as a tubular structure } \\
(0) \text {. Four compartments discernible and under } \\
\text { differentiation ( } 2-3) \text { : atrium, ventricle, sinus } \\
\text { venosus and bulbus arteriosus. }\end{array}$ & $\begin{array}{l}\text { Sketch of atrio-ventricular valve and the first } \\
\text { trabeculae seen in the ventricle (5-6) and atrium } \\
(12-13) \text {. Circulating Bc seen (6) }\end{array}$ \\
\hline Kidney and urinary bladder & $\begin{array}{l}\text { Visible urinary bladder at hatching. Primordial } \\
\text { pronephric tubule (1-2) present and few } \\
\text { undifferentiated haematopoietic cells seen. Renal } \\
\text { corpuscle visible (4). }\end{array}$ & $\begin{array}{l}\text { Proliferation of renal tubules immersed in interstitial } \\
\text { haematopoietic tissue }(6) \text {. Urinary bladder } \\
\text { connected to the kidney via ureter }(6-7) \text {. }\end{array}$ \\
\hline Spleen & $\begin{array}{l}\text { Spleen anlage containing a cluster of mesenchymal } \\
\text { cells and developing capillaries seen (4). }\end{array}$ & $\begin{array}{l}\text { Spleen showing its elliptical shape (6). Visible } \\
\text { macrophagic cells, ellipsoids and sinusoids (13). }\end{array}$ \\
\hline Endocrine elements & $\begin{array}{l}\text { Single pancreatic endocrine element (Langerhans } \\
\text { islet) present }(2-3) \text { within exocrine pancreatic tissue. } \\
\text { First thyroid follicle evident }(3-4) \text {. }\end{array}$ & Two thyroid follicles evident (10). \\
\hline
\end{tabular}


Table 2. - Schematic synthesis of the main ontogenetic events occurring in Chelon labrosus larvae during exogenous (Stage 3) and metamorphic (Stage 4) phases. Numbers in brackets indicate the age (dph) Bphc, bucopharyngeal cavity; Ca, cardias; Ep, exocrine pancreas; Fu, fundus; GG, gastric glands; ILM, inner limiting membrane; Li, liver; Mc, mucous cells; Oe, oesophagus; OLM, outer limiting membrane; ONL, outer nuclear layer; $\mathrm{Pi}$, posterior intestine; Py, pyloric region; Rc, rod cells; Si, supranuclear inclusions; St, stomach.

\begin{tabular}{|c|c|c|}
\hline & Stage 3 (between 14-16 until $22 \mathrm{dph}$ ) & Stage 4 (around 23 dph onwards) \\
\hline Endogenous reserves & Exhausted. & \\
\hline Digestive system & $\begin{array}{l}\text { Mc proliferating in Bphc and Oe (14). } \\
\text { Increase in connective tissue and } \\
\text { external circular muscular layer in Oe; St } \\
\text { surrounded by two smooth muscular layers } \\
\text { (14). Presence of first GG (16). Py caecum } \\
\text { differentiation from the most anterior } \\
\text { intestinal wall (22). }\end{array}$ & $\begin{array}{l}\text { Proliferation of gastric glands (23). Stomach } \\
\text { showing differentiation into three portions: a Ca and } \\
\text { Fu containing GG and Py portion lacks GG (25). } \\
\text { Thickening of musculature of Py region, forming a } \\
\text { typical developed muscular structure or mullet gizzard } \\
\text { (78). Acidophilic protein Si still present in the Pi (78). }\end{array}$ \\
\hline Accessory glands & $\begin{array}{l}\text { Increase in size of Li and Ep. Evident } \\
\text { vacuolization of hepatocytes. Beginning of } \\
\text { the liver segmentation (14-22). }\end{array}$ & $\begin{array}{l}\text { Liver became bilobulated. Pancreatic tissue and } \\
\text { gallbladder fully formed ( } 25 \mathrm{dph}) \text {. }\end{array}$ \\
\hline Swim bladder & $\begin{array}{l}\text { Swim bladder completely developed and } \\
\text { functional (14-16). }\end{array}$ & \\
\hline Eye & $\begin{array}{l}\text { Rc precursors in the basal region of the } \\
\text { ONL (16). Noticeable OLM (16). }\end{array}$ & Rod cells proliferation (23). Noticeable ILM (29). \\
\hline Gills & $\begin{array}{l}\text { Filaments and lamellae increased in length } \\
\text { and number. }\end{array}$ & First Mc in filament epithelium (23). \\
\hline Heart & $\begin{array}{l}\text { Proliferation of ventricular and atrial } \\
\text { trabeculae (14). Completely formed heart } \\
(20-21) \text {. }\end{array}$ & \\
\hline Kidney and urinary bladder & $\begin{array}{l}\text { Appearance of pronephros surrounded by } \\
\text { haematopoietic tissue (14) and a visible } \\
\text { mesonephros (15-16). Considerable } \\
\text { development of convoluted renal tubules } \\
(21-22) \text {. }\end{array}$ & $\begin{array}{l}\text { Haematopoietic tissue increased in size and } \\
\text { concentrated in the cranial and caudal regions. Fully } \\
\text { formed kidney. }\end{array}$ \\
\hline Spleen & $\begin{array}{l}\text { Appearance of splenic sinusoids and } \\
\text { ellipsoids }(17-18)\end{array}$ & $\begin{array}{l}\text { Spleen located ventrally to the swim bladder. } \\
\text { Macrophagic cells, ellipsoids and splenic sinusoids, as } \\
\text { well as reticulum and the different blood cell types were } \\
\text { seen. }\end{array}$ \\
\hline Endocrine elements & $\begin{array}{l}\text { Three developed thyroid follicles visible } \\
\text { (14). A single pancreatic islet still present } \\
\text { (endocrine pancreas) within exocrine } \\
\text { pancreatic tissue (22). }\end{array}$ & Proliferation of thyroid follicles (up to 9 at $78 \mathrm{dph}$ ). \\
\hline
\end{tabular}

of complete reabsorption at $8 \mathrm{dph}$. The oil globule showed the highest absorption rates during the first $24 \mathrm{~h}$ post-hatching, with about $45 \%$ of the oil volume consumed $\left(\mathrm{V}=0.0444 \exp ^{(-0.1671} \mathrm{T}\right)$. A clear reduction in the reabsorption process was observed at the time of mouth opening (4 dph) and until $6 \mathrm{dph}$ (Fig. 2). Histological results revealed that both yolk sac and oil globule reserves were completely reabsorbed at 8 and 12-13 dph (Tables 1 and 2).

Three different periods were detected (Figs 3 and 4 , Table 3 ) in the growth curve (body mass and total length [TL]). The first inflexion point (between periods $\mathrm{A}$ and $\mathrm{B}$ ) was observed at $22 \mathrm{dph}$, whereas the second one was detected at $54 \mathrm{dph}$ (between periods $\mathrm{B}$ and $\mathrm{C})$. Comparison between the slope obtained in each pair of periods was statistically different at both inflexion points ( $\mathrm{t}$-test, $\mathrm{P}<0.05)$. The first $(5-22 \mathrm{dph})$ and third (54-99 dph) periods exhibited a reduced specific growth rate (SGR) of $3.93 \%$ and $6.81 \%$ per day, respectively. However, during the second period (22-54 dph) the growth increased sharply, reaching $13.45 \%$ of body mass per day (Fig. 3). The TL was $3.503 \pm 0.025 \mathrm{~mm}$ at hatching $(0.205 \pm 0.007 \mathrm{mg})$ and $4.415 \pm 0.031 \mathrm{~mm}(0.123 \pm 0.038 \mathrm{mg})$ at $4 \mathrm{dph}$ when the mouth was opened, reaching $8.169 \pm 0.338$ $\mathrm{mm}(0.277 \pm 0.007 \mathrm{mg})$ at $22 \mathrm{dph} ; 15.018 \pm 0.701$ $\mathrm{mm}(19.004 \pm 0.096 \mathrm{mg})$ at $54 \mathrm{dph}$; and $35 \mathrm{~mm}$ $(345.703 \pm 0.036 \mathrm{mg})$ at $99 \mathrm{dph}$.

\section{Histology and histochemistry of organogenesis}

The preflexion larval stage lasted from 8 to $13 \mathrm{dph}$, and was characterized by the full resorption of the yolk and the oil globule. Completion of notochord flexion was achieved around 13-16 dph, and the post-flexion phase occurred between 16 and $22 \mathrm{dph}$, coinciding with the development of anal, caudal, and dorsal fins. An increase in skin pigmentation during the metamorphic stage 4 in notochord post-flexioned larvae was observed. During the lecithotrophic phase, eyes were well pigmented (by $2 \mathrm{dph}$ ) and the visual system was morphologically well-developed and therefore functional from this time.

\section{Digestive system}

During the ontogenetic stage 1, the yolk sac had a homogenous acidophilic vitelline matrix surrounded by a squamous epithelium. At the end of the yolk sac stage the remaining matrix became heterogeneous. The yolk syncytial layer or periblast enclosed the remainder of the yolk ( $8 \mathrm{dph})$, and the oil globule was the last to be reabsorbed (13 dph), thus completing the mixed endo-exogenous feeding phase of this omnivorousdetritivorous species. In newly hatched larvae $(0 \mathrm{dph})$, the digestive tract appeared as a closed undifferentiated straight tube located dorsal to the yolk sac, formed by a 


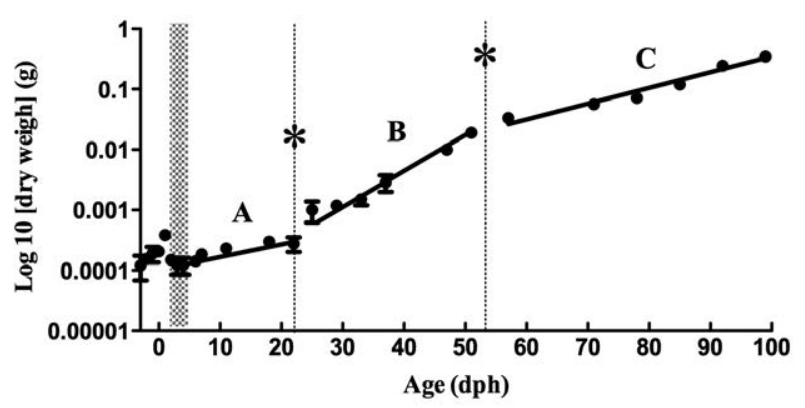

Fig. 3. - Mean weight values of growth in larvae and juveniles of Chelon labrosus as a function of age (1 to $99 \mathrm{dph}$ ). Data are plotted on a logarithmic ordinate grid and values are represented as mean \pm S.E.M $(n=10-30)$. Linear regression equations for each growth stage (bold lines) were estimated by the least-squares regression method using log-transformed data. Vertical dashed lines indicate inflexion periods (i.e. change in regression). Bar represents the moment of the mouth opening (4 days post-hatching, dph). * Represents statistically significant differences between the slope of periods $\mathrm{A}$ and $\mathrm{B}(\mathrm{t}=6.532, \mathrm{P}<0.05)$ and periods $\mathrm{B}$ and $\mathrm{C}(\mathrm{t}=6.398$, $\mathrm{P}<0.05)$.

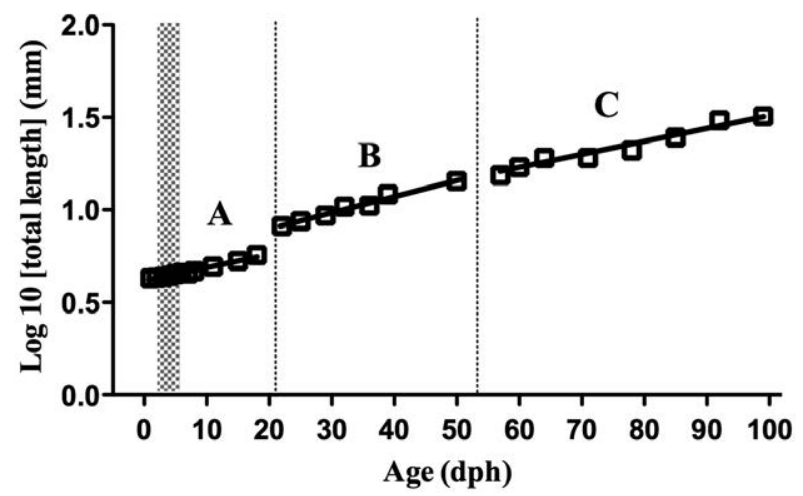

Fig. 4. - A, mean total length data of growth in larvae and juveniles of Chelon labrosus as a function of age from 1 to $99 \mathrm{dph}$. Data are plotted on a logarithmic ordinate grid, and values are represented as mean \pm S.E.M $(n=10-30)$. Linear regression equations for each distinct growth stage (bold lines) were estimated by the least-squares regression method using log-transformed data. Bar represents the moment of mouth opening (4 dph).

single-layer epithelium consisting of simple columnar and cuboidal cells. Progressive changes were detected leading to progressive differentiation of the digestive system into several main segments: buccopharynx, oesophagus and anlage stomach (former foregut), anterior intestine (former midgut) and posterior intestine and rectum (former hindgut). At $4 \mathrm{dph}$, the mouth opened and was differentiated and developed into lower and upper functional-movable jaws, in which mandibular and pharyngeal teeth can already be observed. The first mucous cells and few scattered taste buds appeared at $5 \mathrm{dph}$ in the posterior region of the buccopharyngeal cavity, which communicated with the anterior intestine through a short oesophagus with a narrow lumen. Two different portions were distinguished in the oesophageal mucosa: an anterior region lined by a pseudo-stratified, ciliated epithelium and a dilated posterior region lined by a simple, cuboidal epithelium, from which the future stomach would originate. From 3-4 dph, intestinal segmentation was apparent since the future ileo-rectal valve began to develop and clearly separated the anterior intestine (prevalvular) from the bending posterior
Table 3. - Equation and coefficient of determination $\left(\mathrm{R}^{2}\right)$ of each regression period for mean dry weight and mean total length values (see Figs 3 and 4). DW, dry weight; T, age (dph); TL, total length.

\begin{tabular}{lcc}
\hline Inflexion periods & Equation & $\mathrm{R}^{2}$ \\
\hline Mean dry weight (DW) & $\mathrm{DW}=0.000130 \mathrm{e}^{(0.03936 \mathrm{~T})}$ & 0.8177 \\
$\mathrm{~A}(5-22 \mathrm{dph})$ & $\mathrm{DW}=0.000043 \mathrm{e}^{(0.13451 \mathrm{~T})}$ & 0.9934 \\
$\mathrm{~B}(22-54 \mathrm{dph})$ & $\mathrm{DW}=0.000415 \mathrm{e}^{(0.06814 \mathrm{~T})}$ & 0.9878 \\
$\mathrm{~A}(54-99 \mathrm{dph})$ & & \\
Mean total length (TL) & $\mathrm{TL}=0.6179 \mathrm{e}^{(0.01075 \mathrm{~T})}$ & 0.9874 \\
$\mathrm{~A}(5-22 \mathrm{dph})$ & $\mathrm{TL}=0.7622 \mathrm{e}^{(0.00849 \mathrm{~T})}$ & 0.9743 \\
$\mathrm{~B}(22-54 \mathrm{dph})$ & $\mathrm{TL}=0.8788 \mathrm{e}^{(0.00549 \mathrm{~T})}$ & 0.9648 \\
$\mathrm{~A}(54-99 \mathrm{dph})$ & &
\end{tabular}

(postvalvular) intestinal portion. Both portions showed a single epithelial layer composed of columnar cells with basal nuclei and a strongly eosinophilic brush border (Figs 5 to 8, and Tables 1 and 2).

From 5-6 dph, the first oesophageal goblet cells were detected, increasing in number and size over time. A dilatation in the posterior region of the oesophagus lined by a simple cubic epithelium and a thickening of the mucosal layer were observed, indicating the presumptive gastric stomach formation, which is lined by a simple epithelium with basal nuclei. At this time, the pyloric sphincter appeared, separating the anterior intestinal portion from the developing primordial stomach. Around 5-6 dph, the stomach developed and became folded, and connective tissue and a muscular layer, as well as a thickening of the mucosal layer, were clearly detected from this time onwards. Intestinal increased folds and an evident protein rich brush border lining the enterocytes were visible. Mucous cells were seen for the first time at $6 \mathrm{dph}$ in the anterior and posterior intestinal portions. The first acidophilic supranuclear vesicles containing proteins were visible in the posterior intestine of larvae from $5 \mathrm{dph}$ and persisted throughout the study period (78 dph). The first sign of intestinal lipid absorption within the cytoplasm of enterocytes of the anterior intestinal portion was observed around 8-9 dph (Tables 1 and 2, and Figs 5 to 8).

By $16 \mathrm{dph}$, the stomach showed a pouched shape and its epithelium had differentiated in several structural regions, such as cardias, which are distinguished by a simple cubic epithelium, and the fundic and pyloric portions, which are distinguished by a thicker columnar epithelium. At this time, gastric glands were first evident as aggregates of submucosal acinar cells, concentrated in both cardiac and fundic regions, which are separated by epithelial folds, together with a thick muscular gastric layer. No goblet cells were observed in the stomach region. From 22 to $23 \mathrm{dph}$, the number and length of the mucosa intestinal folds increased progressively. Simultaneously, the intestinal mucosa immediately posterior to the pyloric sphincter showed evident and numerous evaginations, indicating the first sign of the pyloric caeca differentiation and development from the most anterior intestinal wall. In metamorphosing larvae, from $23 \mathrm{dph}$ onwards, an evident proliferation of gastric glands in the cardiac and fundic regions was detected, as well as the transition from a multi-striated to a smooth muscle layer. The three regions (cardias, fundus, and pylorus) were clearly developed between 23-25 dph. By this time, a fully developed stomach containing a muscularis mucosae, a submucosa and a muscular tunica were 


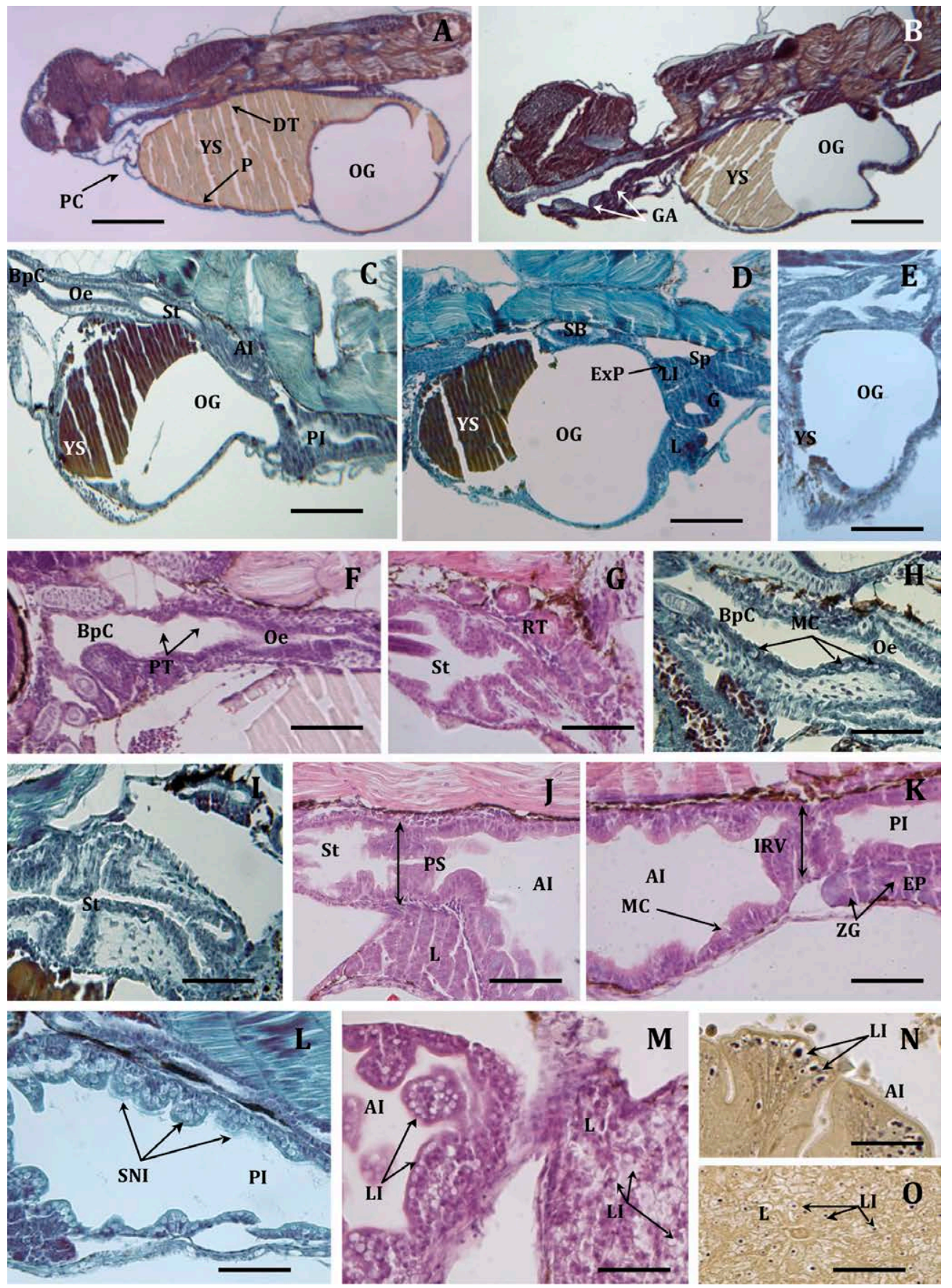

Fig. 5. - Histological sections of the Chelon labrosus during the endo-exotrophic stages. A, 0 days post-hatching (dph) larvae showing an acidophilic homogeneous yolk matrix and adhered lipid droplet close to a straight digestive duct. A tubular heart anlage is seen within pericardiac cavity. B, larvae at 2-3 dph showing a yolk mass with a reduced volume. Note mouth opened. Incipient gills are also discernible at this stage. C, progressive differentiation of the digestive system into different segments (buccopharynx, oesophagus, stomach anlage, anterior and posterior intestine). D, larvae at 3-4 dph showing a slight yolk sac and a still-present oil globule. Exocrine with acidophilic zymogen granules and endocrine (Langerhans islets) pancreatic portions are visible. Swim bladder anlage is also detected at this stage. E, periblast enclosing residual yolk and oil globule is visible in larvae by $7 \mathrm{dph}$. F and G, larvae at 4-5 dph showing the bucopahryngeal cavity (F) with pharyngeal teeth and a developing oesophagus with a pseudo-stratified epithelium and first mucous cells and an incipient stomach (G) as a small pocket covered by a thickened mucosal layer which lacks gastric glands. Renal tubules are proliferating at this stage. H, first mucous cells detected in buccopharyngeal cavity and oesophagus at $5 \mathrm{dph}$. Thickening of mucous and muscular layer are also detected at this stage. I, a more developed and folded stomach with a thickening of mucosal layer is also seen at $5 \mathrm{dph}$. J, 5-6 dph larvae showing pyloric sphincter separating the anterior intestinal portion from the developing anlage stomach. Noticeable increase in size of liver is also seen at this stage. K, first mucous cells present on anterior intestine at 5-6 dph. Note the presence of ileorectal valve separating anterior intestine from the bending posterior intestinal portion. Exocrine pancreas increased in size at this stage. L, acidophilic supranuclear inclusions first detected in the posterior intestine at $6 \mathrm{dph}$. $\mathrm{M}$ to O, larvae at 8-9 dph showing osmiophilic lipid inclusions in enterocytes from the anterior and median intestine and within cytoplasm of hepatocytes. Scale bar represents (A, B) 500 um; (C-E) 300 um; (F-O) 200 um. Haematoxylin-VOF (A-E, H, I, L). Haematoxylin-eosin (F, $\mathrm{G}, \mathrm{J}, \mathrm{K}, \mathrm{M})$. Osmium tetroxide posfixation (N, O). AI, anterior intestine; BpC, bucopharyngeal cavity; DT, digestive tube; ExP, exocrine pancreas; G, gut; GA, gills anlage; IRV, ileorectal valve; L, liver; LI, Langerhans islet; Lin, lipid inclusions; MC, mucous cells; Oe, oesophagus; OG, oil globule; P, periblast; PC, pericardic cavity; PI, posterior intestine; PS, pyloric sphincter; PT, pharyngeal teeth; RT, renal tubules; SB, swim bladder; SNI, supranuclear inclusions; Sp, spleen; St, stomach; YS, yolk sac; ZG, zymogen granules. 

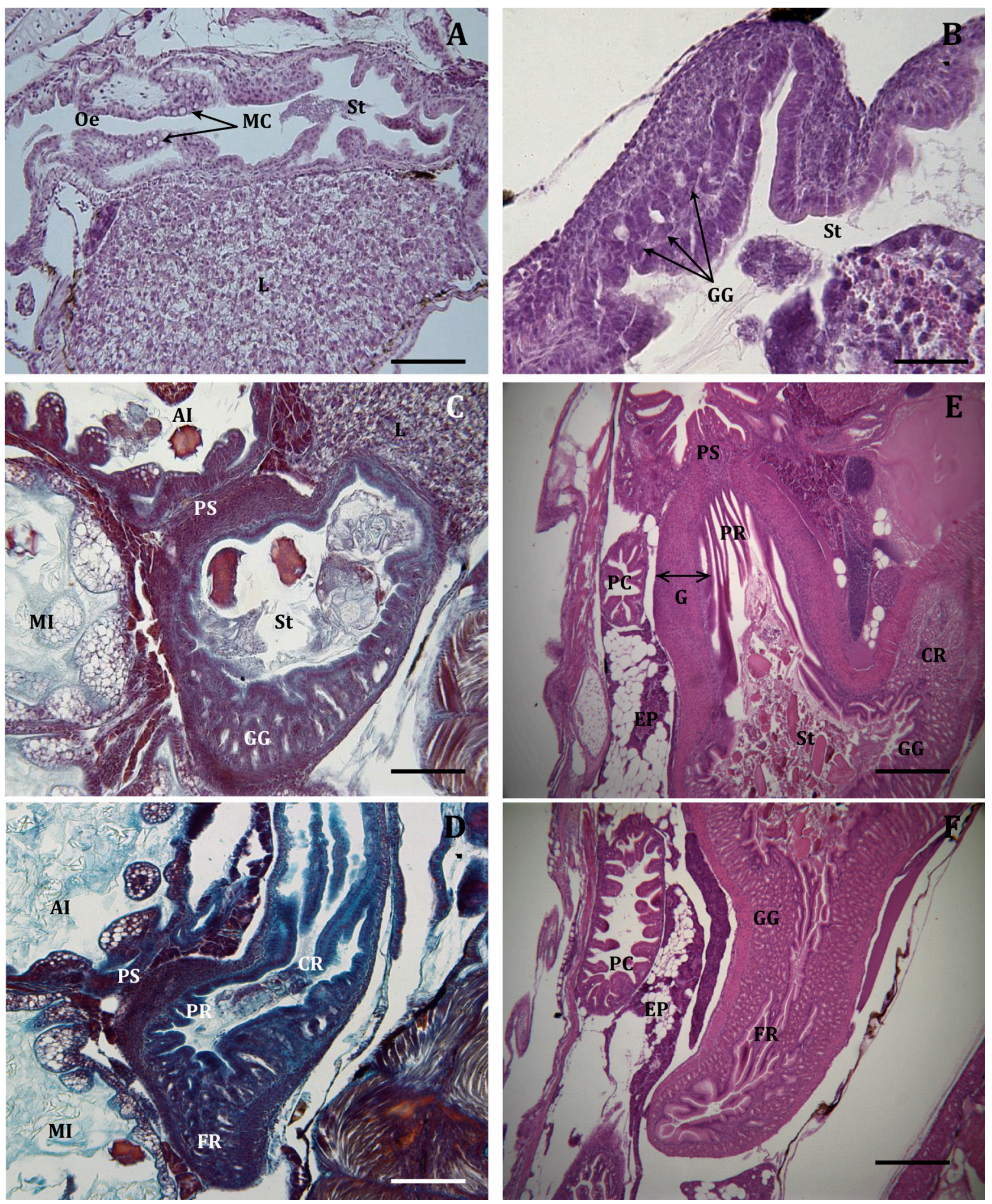

Fig. 6. - Histological sections of Chelon labrosus larvae between 14 and 78 days post-hatching (dph) with special emphasis on digestive system development. A, 14 dph larvae showing oesophageal cavity with stratified epithelium and an increase in mucous cells and of connective tissue and external circular muscle layer. Liver shows a noticeable increase in size at this stage. B, first gastric glands are clearly visible in stomach mucosa at $16 \mathrm{dph}$. C, stomach at $23 \mathrm{dph}$ showing differentiation into three portions: cardias, pylorus and fundus. D, musculature thickening of pyloric portion as a precursor of mullet typical gizzard stomach structure is evident. Proliferation of exocrine portion of pancreas is detected between intestinal mesenteries. $\mathrm{E}$ and $\mathrm{F}$, fully developed stomach containing a muscularis mucosae, submucosa and tunica muscularis is clearly distinguished and surrounded by the outer serous membrane ( $78 \mathrm{dph})$. The typical mullet gizzard muscular structure in the stomach pyloric region (without gastric glands) is clearly distinguished and fully developed at this stage. Scale bar represents (A, B, E, F) $200 \mu \mathrm{m}$; (C, D) $300 \mu \mathrm{m}$. Haematoxylin-eosin (A, B, E, F). Haematoxylin-VOF (C, D). AI, anterior intestine; CR, cardias region; EP, exocrine pancreas; FR, fundus region; G, gizzard; GG, gastric glands; MC, mucous cells; MI, medium intestine; Oe, oesophagus; PC, pyloric caecum;

PR, pyloric region; PS, pyloric sphincter; St, stomach. 

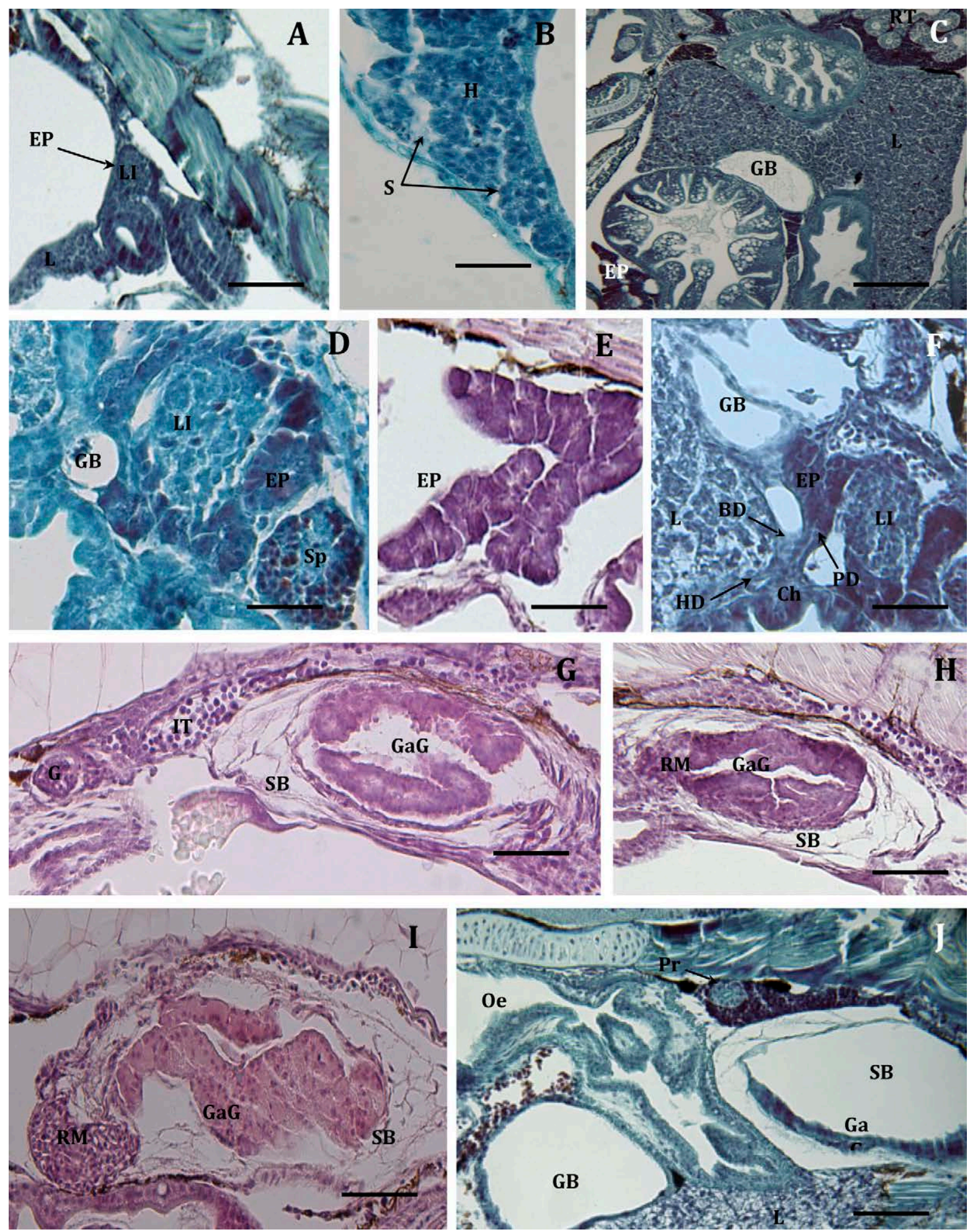

Fig. 7. - Histological development of accessory glands and swim bladder of Chelon labrosus. A, 2 days post-hatching (dph) larvae showing incipient liver and exocrine pancreas with a single Langerhans islet (endocrine portion). Note hepatocytes as basophilic cells with round nuclei and nucleoli and pancreocytes as polyhedral basophilic cells. B, larvae at 4 dph showing hepatocytes grouped between sinusoids, with a granular cytoplasm and small lipid vacuoles. C, liver fully developed at $25 \mathrm{dph}$ becoming bilobulated. Gall bladder fully functional at this stage. D, larvae at 3 dph showing exocrine pancreas containing dense zymogen granules and a gall bladder formed by squamous epithelium. Spleen with macrophagic cells, ellipsoids and sinusoids is clearly visible at this stage. E, exocrine pancreas increased in size and development and extended dorsally along the digestive tract in a 5-6 dph larvae. F, larvae at $8 \mathrm{dph}$ showing pancreatic bile and choledocus ducts opening into the anterior intestinal portion. G, Chelon labrosus larvae at 4 dph showing an early development of rete mirabile and gas gland from the swim bladder and presence of a renal corpuscle in mesonephros immersed in haematopoietic tissue. At $6 \mathrm{dph}(\mathrm{H})$ gas gland and rete mirabile are completely developed, and at 14-16 dph (I) swim bladder is completely developed and functional and inflated at $18 \mathrm{dph}(\mathrm{J})$. Scale bar represents (A to I) $200 \mu \mathrm{m}$; (J) $300 \mu \mathrm{m}$. Haematoxylin-VOF (A-D, F, J) and haematoxylin-eosin (E, G, H, I). BD, bile duct; Ch, choledochus; EP, exocrine pancreas; G, glomerulus; GaG, gastric gland; GB, gall bladder; H, hepatocytes; HD, hepatic duct; L, liver; LI, Langerhans islet;

OE, oesophagus; PD, pancreatic duct; Pr, pronephros; RM, rete mirabile; RT, renal tubules; S, sinusoids; SB, swim bladder; Sp, spleen. 

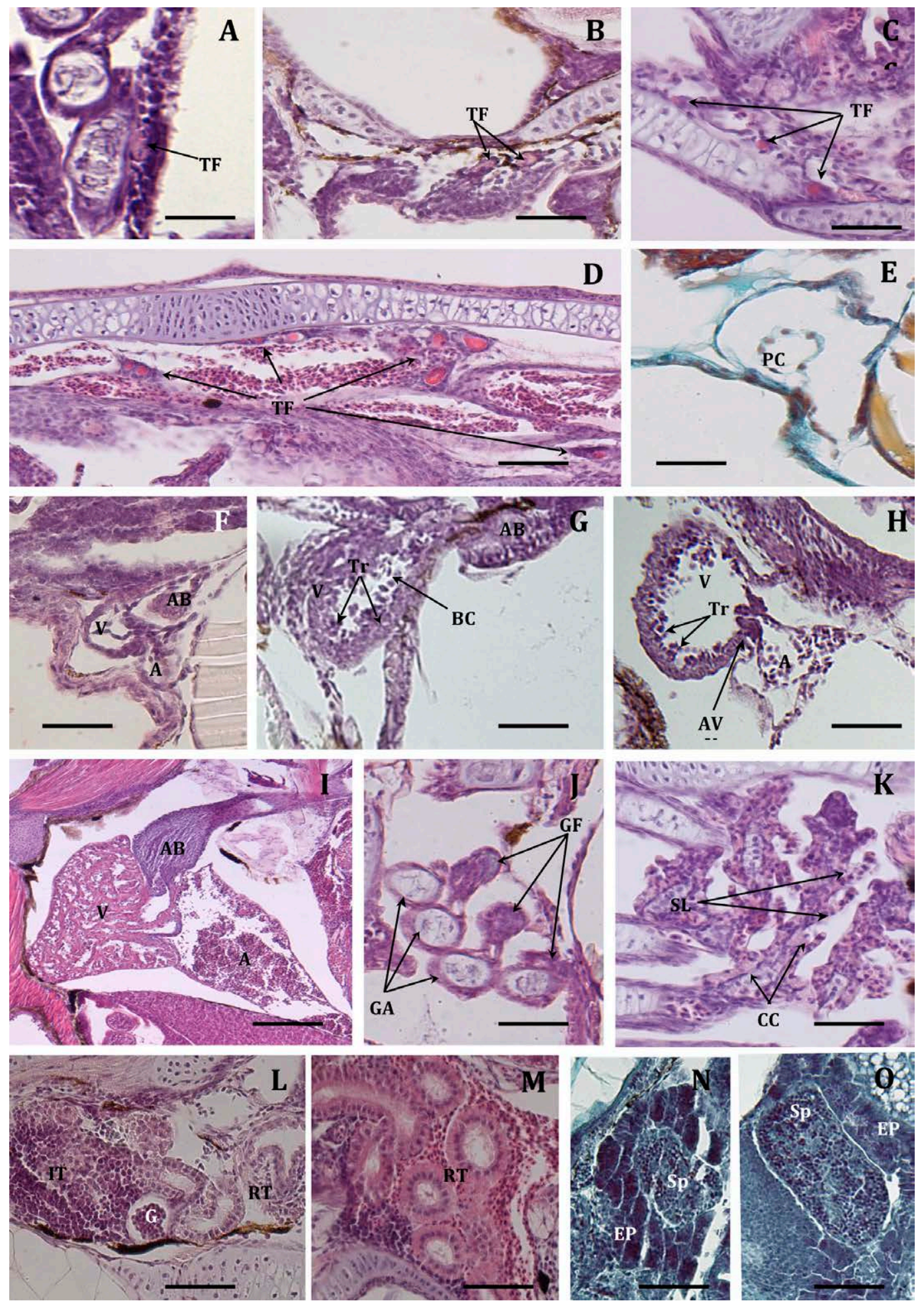

Fig. 8. - Histological sections during development of Chelon labrosus with special emphasis on thyroid gland (A to D) and cardiovascular (E to I) respiratory-osmoregulatory ( $\mathrm{J}, \mathrm{K}$ ), excretory and haematopoietic ( $\mathrm{L}$ to $\mathrm{O}$ ) systems. A, first thyroid follicle seen at 3 days post-hatching (dph) and a thyroid proliferation from $10 \mathrm{dph}$ onwards: 2 follicles at $10 \mathrm{dph}(\mathrm{B}), 3$ at $14 \mathrm{dph}(\mathrm{C})$ and up to 9 at $22 \mathrm{dph}$ (D). Larvae at hatching (E) showing primordial pericardiac cavity as a tubular structure. Four heart chambers are discernible and differentiating at 2-3 dph (F). 5 dph larvae $(\mathrm{G})$ showing circulating blood cells, stratum compactum from ventricular wall, as well as trabecular proliferation. At $12 \mathrm{dph}(\mathrm{H})$ trabeculae are first seen in the atrium. Atrio-ventricular valve is clearly distinguished at this stage. Heart cavities are completely formed at $20 \mathrm{dph}$ (I). Histological development of gills in Chelon labrosus larvae: gill filaments, vascular structures and lamellae are differentiating at $4 \mathrm{dph}(\mathrm{J})$ and show a complete development at $14 \mathrm{dph}(\mathrm{K})$. Pronephric and mesonephric regions of kidney (L) at $14 \mathrm{dph}$ showing abundant haematopoietic tissue, renal tubules and glomerulus. Proliferation of renal tubules in mesonephric portion (M) at $16 \mathrm{dph}$. Spleen showing its elliptical shape at $12 \mathrm{dph}(\mathrm{N})$, being fully formed and functional from $22 \mathrm{dph}$ onwards (O). Scale bar represents (A to C) $150 \mu \mathrm{m}$; (D) $300 \mu \mathrm{m}$; (E to K) $50 \mu \mathrm{m}$; (L to O) $150 \mu \mathrm{m}$. Haematoxylin-eosin (A-D, F-M) and haematoxylin-VOF (E, N, O). A, atrium; AB, aortic bulb; AVV, atrioventricular valve; BC, blood cells; CC, chloride cells; EP, exocrine pancreas; G, glomerulus; GA, gill arches; GF, gill filaments; IT, interstitial tissue; PC, pericardial cavity; RT, renal tubules; SL, secondary lamellae; Sp, spleen; TF, thyroid follicles; Tr, trabeculae; V, ventricle. 
Table 4. - Histochemical distribution of glycoconjugates and proteins during the endo-exogenous phase (0-13 dph) of Chelon labrosus. Results are expressed as semi-quantitative assessment of colour intensities or histochemical reactivity. Estimated scale to evaluate the presence of macromolecules: 0 , negative or unreactive; $1-2$, weak-moderate staining; 3-4, strong reactivity.

\begin{tabular}{|c|c|c|c|c|c|c|c|c|c|c|c|}
\hline & $\begin{array}{l}\text { Neutral } \\
\text { glycocon- } \\
\text { jugates }\end{array}$ & $\begin{array}{c}\text { Carboxylated } \\
\text { glycoconju- } \\
\text { gates }\end{array}$ & $\begin{array}{l}\text { Sulphated } \\
\text { glycocon- } \\
\text { jugates }\end{array}$ & Glycogen & $\begin{array}{l}\text { Proteins } \\
\text { in general }\end{array}$ & Lys & Tyr & Arg & $\mathrm{CySH}$ & CySSCy & Trp \\
\hline \multicolumn{12}{|l|}{ Endogenous phase (0-4 dph) } \\
\hline Yolk sac & 2 & 0 & 0 & 2 & $1-2$ & 0 & $0-1$ & $0-1$ & 0 & $0-1$ & 0 \\
\hline Liver/Hepatocytes & $0-1$ & $0-1$ & 0 & $1-2$ & $1-2$ & 0 & 0 & 0 & 0 & $0-1$ & 1 \\
\hline Exocrine pancreas/zymogen granules & $0-1$ & $0-1$ & $0-1$ & 0 & $0-1$ & 0 & 0 & 0 & 0 & $0-1$ & $0-1$ \\
\hline \multicolumn{12}{|l|}{ Endo-exogenous phase $(5-13 \mathrm{dph})$} \\
\hline Yolk sac & 1 & 0 & 0 & 1 & $2-3$ & 0 & $1-2$ & 1 & 0 & $1-2$ & 0 \\
\hline Liver/Hepatocytes & $2-3$ & $0-1$ & 0 & 3 & 3 & $0-1$ & $0-1$ & $0-1$ & 0 & $0-1$ & 0 \\
\hline Exocrine pancreas/zymogen granules & $0-1$ & $0-1$ & $0-1$ & 0 & 3 & $0-1$ & 0 & 0 & 0 & $1-2$ & 3 \\
\hline
\end{tabular}

Table 5. - Histochemical distribution of glycoconjugates and proteins during the exogenous feeding phase (14-22 dph) of Chelon labrosus. Results are expressed as semiquantitative assessment of colour intensities or histochemical reactivity. Estimated scale to evaluate the presence of macromolecules: 0, negative or unreactive; 1-2, weak-moderate staining; 3-4, strong reactivity.

\begin{tabular}{|c|c|c|c|c|c|c|c|c|c|c|c|}
\hline & $\begin{array}{l}\text { Neutral } \\
\text { glycocon- } \\
\text { jugates }\end{array}$ & $\begin{array}{c}\text { Carboxylated } \\
\text { glycoconju- } \\
\text { gates }\end{array}$ & $\begin{array}{l}\text { Sulphated } \\
\text { glycocon- } \\
\text { jugates }\end{array}$ & Glycogen & $\begin{array}{l}\text { Proteins } \\
\text { in } \\
\text { general }\end{array}$ & Lys & Tyr & Arg & $\mathrm{CySH}$ & CyssCy & $\operatorname{Trp}$ \\
\hline \multicolumn{12}{|l|}{ Digestive tract } \\
\hline \multicolumn{12}{|l|}{ Oesophagus } \\
\hline Epithelium & $0-1$ & $0-1$ & 1 & 0 & $0-1$ & $0-1$ & $1-2$ & 1 & $1-2$ & $1-2$ & 0 \\
\hline Mucous cells & $3-4$ & 3 & $2-3$ & 0 & 0 & 0 & 0 & 0 & 0 & $1-2$ & 0 \\
\hline \multicolumn{12}{|l|}{ Stomach } \\
\hline Epithelium & $1-2$ & $1-2$ & $0-1$ & 0 & $3-4$ & $0-1$ & $0-1$ & 0 & 0 & 1 & 0 \\
\hline Gastric glands (first evidence at $16 \mathrm{dph}$ ) & 2 & $1-2$ & $0-1$ & 0 & 3 & $0-1$ & 1 & $0-1$ & 0 & $1-2$ & $3-4$ \\
\hline \multicolumn{12}{|l|}{ Intestine } \\
\hline Epithelium/enterocytes & 0 & 0 & 0 & 0 & 3 & $0-1$ & 1 & $0-1$ & 0 & $1-2$ & 0 \\
\hline Mucous cells & $2-3$ & $2-3$ & 0 & 0 & 0 & 0 & 0 & 0 & 0 & 0 & 0 \\
\hline Supranuclear inclusions & 0 & 0 & 0 & 0 & 4 & 0 & 4 & 0 & $3-4$ & 0 & 0 \\
\hline Brush border & $0-1$ & 0 & 0 & $1-2$ & 3 & 0 & 0 & 0 & 0 & 0 & $1-2$ \\
\hline \multicolumn{12}{|l|}{ Accesory glands } \\
\hline Liver/Hepatocytes & $1-2$ & $0-1$ & 0 & $3-4$ & $3-4$ & $0-1$ & 1 & $0-1$ & 0 & $1-2$ & 0 \\
\hline Exocrine pancreas/zymogen granules & $1-2$ & $0-1$ & 0 & 0 & $3-4$ & $0-1$ & 0 & $0-1$ & 0 & 2 & $3-4$ \\
\hline
\end{tabular}

clearly distinguished and surrounded by the outer serous membrane. From 22-23 dph, and especially around 78 $\mathrm{dph}$, the musculature surrounding the stomach pyloric region became progressively more developed and more noticeable to form the typical muscular pyloric structure or mullet gizzard. At this time, pinocytotic supranuclear vesicles were still present in the posterior intestine of young juveniles (Tables 1 and 2, and Figs 5 to 8 ).

During the resorption process, yolk mass adopted a progressive heterogeneous acidophilic appearance (light green and orange $\mathrm{G}$ from VOF dye). Neutral glycoconjugates, glycogen and proteins were evident in the yolk sac matrix. Oil globule was composed by neutral lipids (unsolubilized with osmium tetroxide). Cytoplasm of hepatocytes contained glycogen, proteins and neutral lipids. Neutral and acidic glycoproteins were weakly detected in the basophilic exocrine pancreas, which contained abundant acidophilic zymogen granules of protein nature (especially rich in tryptophan, cystine, lysine and arginine). The digestive epithelium contained a weak presence of neutral and acidic glycoconjugates. Mucous cells distributed along the buccopharyngeal cavity, oesophagus and intestine synthesized and secreted neutral and acidic mucins (carboxylated and/or sulphated). Eosinophilic supranuclear inclusions present in the posterior intestine showed abundant proteins, especially rich in tyrosine and cysteine. At histochemical level, the gastric glands (16 dph) showed abundant tryptophan, cystine and tyrosine-rich proteins, and a weak reactivity for arginine and lysine (Tables 4 and 5).

\section{Accessory digestive glands and other organ systems}

From 2-3 dph, both the incipient liver and pancreas appeared as a cord-like structure lying between the yolk sac wall and the developing gut, and both were formed by irregular shaped, basophilic cells, round nuclei and prominent nucleoli. The liver was well developed and functional by $4 \mathrm{dph}$ (mouth opening), showing hepatocytes grouped between sinusoids, with a granular cytoplasm. By this time, circulating blood cells between sinusoids were visible. The liver increased in size and became bi-lobulated at $25 \mathrm{dph}$. From $3 \mathrm{dph}$, the rudimentary exocrine pancreas was detected between the yolk sac and developing gut. It was formed by polyhedral basophilic cells with round basal nuclei and containing dense eosinophilic protein zymogen granules at the apical cytoplasmic portion. From 5-6 dph, the opening of the main pancreatic ducts into the anterior intestine was visible, after the pyloric sphincter. The first and single endocrine Langerhans islet within the exocrine pancreas was visible by 2-3 dph (Tables 1 and 2, and Figs 5 to 8).

From 2-3 dph, the gall bladder was visible and formed by a squamous epithelium, lying between the yolk sac wall, the liver and the developing exocrine pancreas. The opening of the bile and choledochus ducts into the anterior intestinal portion after the pyloric sphincter was also detected around 5-6 dph, as seen with pancreatic ducts. The primordial swim bladder (2 dph) was lined with a columnar epithelium and 
surrounded by loose connective tissue, which was formed as an evagination of the posterior dorsal wall of the developing gut. An early development of the gas gland and rete mirabile was evident at 4-5 dph. From this time, the gas gland comprised two layers of simple cubic epithelium, whereas a group of undifferentiated cells on the posterior area of the gas chamber formed the rete mirabile, which was attached to the anteroventral epithelium of the bladder. After swim bladder inflation, coinciding with stomach gastric gland differentiation, most epithelial cells were squamous, except for a small crescent of low columnar cells that remained in the antero-ventral region, corresponding to the gas gland. The rete mirabile proliferated and the number of capillaries increased, containing blood corpuscles connected by this vascular rete. The posterior edges of the bladder protruded and seemed to be the residual tissues of the pneumatic duct. When the swim bladder inflation failed, as seen in few larvae, the columnar cells increased and completely filled the lumen of the bladder, which contained abundant eosinophilic mucus-like substances (Tables 1-2, 4-5, and Figs 5 to 8).

The early larval development of the thyroid gland, which was located adjacent to the ventral aorta and near to the developing heart, consisted of a single follicle (at 3-4 dph), containing a small number of ovoid epithelial cells surrounding an eosinophilic and homogeneous colloid material without vacuoles. Between 5-14 dph, a gradual proliferation of follicles was evident, and they increased in size and number until the first month of larval life. At this time, follicles had colloid-filled lumens and were surrounded by a glandular epithelium, which was composed of cylindrical and cuboidal cells with rounded nuclei located near the basal membrane and containing cytoplasmic acidophilic granules. The cubic epithelium of the thyroid follicles showed weak histochemical reactions for neutral glycoconjugates, and the colloid material contained abundant proteins and neutral mucosubstances. The loose connective tissue surrounding the thyroid follicles was highly vascularized, and nuclei of the follicle cells were in contact with endothelial lining of the capillaries. (Tables 1 and 2, Fig. 8).

The gill anlage was visible at $1 \mathrm{dph}$ and the first signs of chondrogenesis were discernible by $3 \mathrm{dph}$. The primordial gill filament appeared from $4 \mathrm{dph}$, and the first chloride cells by 5-6 dph. Lamellae differentiation was first detected by $8-10 \mathrm{dph}$ and from this time filaments and gill lamellae increased in number and size. The first mucous cells appeared in filament epithelium from $23 \mathrm{dph}$. At hatching, the pericardial cavity appeared as a tubular structure, located cephalically in the coelomic cavity and ventral to the gill anlage. From 2-3 $\mathrm{dph}$, the first differentiation into four heart compartments (atrium, ventricle, sinus venous and auricle) was discernible. Considerable proliferation of ventricular and atrial trabeculae was evident from $14 \mathrm{dph}$. A welldeveloped heart was visible from 20-21 dph onwards. In newly hatched larvae, the urinary bladder was well visible. Several renal structures, such as primordial mesonephric and pronephric portions, with the first undifferentiated haematopoietic cells (1-2 dph) was visible. From $4 \mathrm{dph}$, a renal corpuscle was visible and from this time a major proliferation of renal tubules and corpuscles immersed in the interstitial tissue was observed, in addition to some visible epithelioid- or macrophage-like cells. From 14 dph a well-developed and structurally formed pronephros with haematopoietic tissue and a visible mesonephros (15-16 dph) was evident. From 22-23 dph all renal structures and cell types showed significant proliferation and development. A primordial spleen anlage that consisted of a few blast cells was visible by $4 \mathrm{dph}$. The beginning of a capsule composed of mesenchymal strands was evident. A few macrophagic cells, ellipsoids and splenic sinusoids, as well as epithelioid-like reticulum type cells, were observed for the first time around 12-13 dph. A primordial lymphoid tissue appeared as white and diffuse areas within the haematopoietic tissue. From $22 \mathrm{dph}$, the spleen was well formed, with distinct architectural zones divided by an early fibrous tissue. Well-developed ellipsoids and epithelioid cells were present, and the spleen remained mainly erythroid throughout the larval period studied (Tables 1 and 2, and Figs 5 to 8 ).

\section{Visual system}

Newly hatched larvae had rudimentary eyes with a thin gap, the optic ventricle, which separated the nondifferentiated and unpigmented epithelium composed of flattened cells, and was surrounded by a sclera formed by connective tissue and composed of undifferentiated cells without stratification. The prominent lens was a spherical cellular mass close to the cornea. The most superficial epithelial cells were cubic and the remaining fibers were tall; they converged towards the posterior pole of the lens. The undifferentiated retina consisted of a pseudo-stratified columnar epithelium, the neuroblastic layer, with abundant mitotic figures in the scleral surface and sparse pyknotic nuclei with no clear plexiform layers. Mitotic nuclei and apoptotic cells were always identified in the marginal proliferative zone. The developmental pattern of the retina followed a central to peripheral gradient. The lens structure had two differentiated layers: an external layer of epithelial cells surrounded by a non-nucleated lens fiber layer formed by highly modified epithelial cells, and the neural retina, which became differentiated. The majority of the important structural changes in the retina occurred during the endogenous feeding phase. By $2 \mathrm{dph}$, the first cone-type photoreceptor differentiation and significant pigmentation were detected. The emergence of both inner and outer nuclear layers (INL and ONL), the ganglion layer (GCL), and the inner and outer plexiform layers (IPL and OPL) occurred simultaneously in the central and peripheral regions of the retina. From 2-4 dph, the different retinal layers were observed, from outer to inner zones, on the basis of the size and appearance of their nuclei: the ONL, formed by a row of nuclear segments of the presumptive single cones and composed of columnar nuclear bodies; the INL, formed by presumptive round bipolar cells; the IPL, the first layer that appeared, formed by the neural 

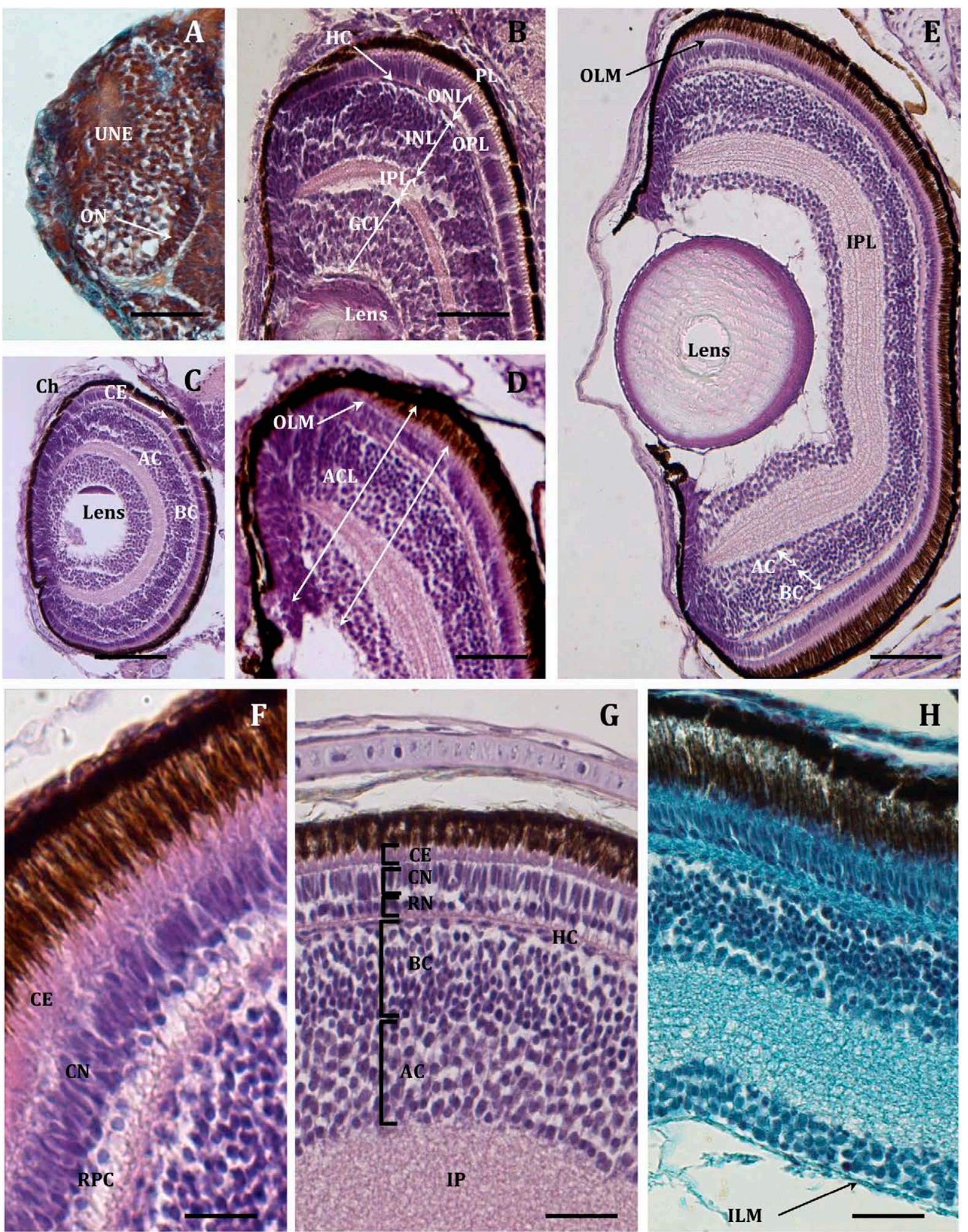

Fig. 9. - Histological development of the retina of Chelon labrosus larvae. A, larvae at hatching showing a developing retina of undifferentiated cells. An outer nuclear layer of single cells is clearly distinguished. B, larvae at 2 dph showing differentiated retinal layers: a pigmented epithelium followed by an outer nuclear layer, an outer plexiform layer an inner nuclear layer of undifferentiated cells, and an inner plexiform layer and finally a ganglion cell layer. Between outer plexiform and inner nuclear layers, a layer of horizontal cells is clearly distinguished at this stage. C, larvae at $4 \mathrm{dph}$ showing inner nuclear layer differentiated into two substrates amacrine and bipolar cell layers. D, larvae at $6 \mathrm{dph}$ showing a retina thickening in the temporal area into an area lateralis. Note a developing choroid surrounding the retina. E and F, rod cell precursors in the outer nuclear layer at $16 \mathrm{dph}$. The outer limiting membrane is evident at this stage. G, retina at $23 \mathrm{dph}$ showing rod cells proliferation and complete development of retinal layers. H, inner limiting membrane is noticeable at $29 \mathrm{dph}$. Scale bar represents (A-D) 150 $\mu \mathrm{m}$; (E) $300 \mu \mathrm{m} ;(\mathrm{F}-\mathrm{H}) 50 \mu \mathrm{m}$. Haematoxylin-VOF (A, H) and haematoxylin-eosin (B-G). AC, amacrine cells; AL, area lateralis; BC, bipolar cells; CE, cone ellipsoids; CN, cone nucleus; $\mathrm{Ch}$, choroid; GCL, ganglion cell layer; HC, horizontal cells; ILM, inner limiting membrane; INL, inner nuclear layer; IPL, inner plexiform layer; OLM, outer limiting membrane; ONL, outer nuclear layer; OPL, outer plexiform layer; PL, pigmentary layer; RN, rod nucleus; RPC, rod precursor cells; UNE, undifferentiated neural epithelium. 
dendrites located in both the INL, and the GCL, which was composed of several rows of ganglion cells. At 4 $\mathrm{dph}$, the pigment epithelium was clearly evident surrounding the ONL. The cones, the only photoreceptors recognizable at this larval age, had a small inner segment and a long outer segment interdigitating epithelial cell processes. A single layer of horizontal cells was also evident in the OPL and between the ONL and the INL. Around $6 \mathrm{dph}$, the ventro-temporal zone of the retina thickened into an area lateralis and in a nasal direction. From $16 \mathrm{dph}$ onwards, several transitional cells, presumably rod cell precursors, were incorporated into the basal region of the ONL from the INL, and a considerable proliferation of cones and differentiating rod cells was detected, particularly from $22 \mathrm{dph}$. The three nuclear layers (ONL, INL and GCL) were separated by synaptic interactions of two plexiform layers (OPL, IPL). The ONL, holding all the somata of photoreceptors arranged into several rows, was prominent, and cone and rod nuclei were visualized. The INL was composed of three cell types: horizontal cells, contacting with photoreceptors; round diffuse bipolar cells, synapsing with several photoreceptors; and amacrine cells, which are in contact between ganglion cells from the GCL. The occurrence of displaced bipolar cells, displaced amacrine cells and displaced ganglion cells, with their perikarya located in the ONL, GCL and INL, was evident. The glial or somata Müller cells appeared to send processes to both plexiform layers (the IPL and the OPL). An inner (or internal) limiting membrane (ILM), the basal lamina of the supporting Müller glial cells, separated the vitreous body from the retina, while an outer (or external) limiting membrane (OLM) separated the photoreceptor layer (PL) (cone and rod inner segments) from the ONL (Fig. 9).

During the first month of larval life, the visual system was formed by a duplex retina containing both types of photoreceptors, cones and rods, as well as a developed cornea, sclera and iris. At this time, the eye consisted of all typical mature structured retina layers and contained different cell types and fibers: (1) pigment epithelium; (2) the OLM; (3) the ONL (cone and rod photoreceptors with outer and inner segments); (4) the OPL (synaptic terminals of cones, rods, horizontal and bipolar cells); (5) the INL (bipolar, amacrine and horizontal cells); (6) the IPL (connections between bipolar, amacrine and ganglion cells); (7) the GCL (ganglion cells); (8) the OFL; and (9) the ILM. The mature retina also contained the typical marginal proliferative zone with undifferentiated cells and active sites of cellular proliferation and apoptosis, which were always distinguished in our study by differential nucleus morphologies and specific tinctorial staining affinities.

\section{DISCUSSION}

Chelon labrosus is a Mugilidae species with a typical omnivorous-detritivorous feeding strategy and with high potential for a sustainable aquaculture diversification (Cataudella et al. 1988, Boglioni et al. 1992, Crosseti and Cataudella 1995, Yúfera and Arias
2010). Different zootechnical conditions can affect the adequate development, growth and survival of larvae and production of juveniles of quality. The general development of marine fish eggs and larvae follows a similar pattern, but apparently important speciesspecific differences exist with regard to different biotic and abiotic factors (feeding regimes and behaviours, temperature and climate ranges and others), and with regard to a particular sequential timing of development and functionality of the main organ systems during the larval life (Govoni et al. 1986, Dinis et al. 1999, Gisbert et al. 2008, Pittman et al. 2013).

\section{Growth pattern}

As for many other marine altricial fishes (Balon 1981, 1986, Stroband and Dabrowski 1981, Fuiman 1983), the growth pattern of C. labrosus was dependent upon timely developmental ontogenetic changes occurring during early larval periods and especially during the lecitotrophic, endo-exotrophic and metamorphosis phases. A slow growth pattern during the first three weeks after hatching was evident, as well as an extended period of remaining yolk and oil reserves $(8-13 \mathrm{dph})$ that lasted longer than in many other altricial marine fish (Govoni et al. 1986, Falk-Petersen 2005). This fact contrasts with the generalized principle that the mixed feeding period was relatively short in the Mugilidae family (Bruslé 1981b). For striped mullet, Mugil cephalus, a low growth period was also detected during the early larval development, with the highest mortality during the initial 15 dph (Eda et al. 1990). The endogenous reserves were depleted moderately fast $(78 \%$ of yolk and $35 \%$ of oil globule) until mouth opening, by $4 \mathrm{dph}$. Data reported by Ben Khemis et al. $(2006,2013)$ were $64 \%$ and $36 \%$ at $5 \mathrm{dph}$. The typical growth pattern of this mullet species with slow increases in body mass rates during the first inflexion point (at $22 \mathrm{dph}$; SGR $3.93 \%$, present study), and an extended mixed endo-exogenous feeding period (until $13 \mathrm{dph}$ ) seems to be a common feature in early larval stages of the Mugilidae family. This feature could be due to allocation of available building materials giving priority to physiological changes rather than to size and growth, and it would allow larvae to attain earlier a better nutritional status that would enhance their growth performance at latter stages. Morphogenesis and differentiation were very intense processes during first weeks of larval life of Chelon labrosus (Boglioni et al. 1992, Ben Khemis et al. 2006, 2013). Feeding, sensory, digestive and respiratory systems grew and developed giving priority to physiological changes rather than to size growth during the first inflexion period, which was distinguished by reduced SGR but intense morphogenesis and differentiation processes. Organogenesis and allometric changes indicated that development priorities affected feeding efficiency, by improving prey detection ability (sensory system development), ingestion capacity (head growth), assimilation performance (digestive functionality) and respiration efficiency (gill development). The second inflexion episode affected post-flexion larvae and was 
characterized by an acceleration of growth (23-54 dph; SGR $13.45 \%$ ). This period was distinguished by fast growth of the trunk and tail, acquisition of adult axial muscle distribution and completion of gill filament development, improving swimming and locomotion and respiratory performance. This inflexion corresponded to the transition towards the metamorphosing stage, as indicated by later isometric growth, progressive maturation of axial musculature and the acquisition of juvenile phenotype (Ben Khemis et al. 2006, 2013). Other studies have found that slow growth and high mortality of fish larvae may be linked with the development of the feeding apparatus (jaws, skull, teeth) and with other structures of the post-cranial skeleton (Löffler et al. 2008, Ott et al. 2012). As mentioned above, the development of these structures, some sensory organs and truck musculature is usually prioritized in altricial larvae to improve success of feeding and escaping from predators. However, no massive mortalities due to starvation were observed in our study, in which prey were always available.

\section{Ontogeny of the digestive tract and other organ systems}

In fishes, the development and differentiation of organ systems and structures proceeds continuously during the early embryonic and larval stages and the metamorphosis phase, in accordance with gradual improvements in functionality. The ontogeny of C. labrosus was similar to that describe for other teleosts with altricial larvae (Stroband and Dabrowski 1981, Govoni et al. 1986, Falk-Petersen 2005, Zambonino-Infante et al. 2008), but with a particular time sequence in the main ontogenetic events. During the endogenous feeding phase, prior to mouth opening, nutrient acquisition relied exclusively on the yolk-oil reserves assimilated through the yolk syncytial layer. Yolk sac and lipid absorption is the result of the intracellular activity of the periblast (Govoni et al. 1986, Deplano et al. 1991, Sarasquete et al. 1993a,b, 1996, Falk-Petersen 2005). The opening of the buccal cavity and anus was one of the first major developments of the digestive system. The early appearance of pharyngeal teeth and the formation of longitudinal folds and presence of goblet cells in the oesophagus were also directly linked to the ability of fish larvae for early commencement of exogenous feeding (Sarasquete et al. 1995, Falk-Petersen 2005, Zambonino-Infante et al. 2008). When the mouth opened (at $4 \mathrm{dph} ; 4.4 \mathrm{~mm}$ TL), movable jaws and the appearance of pharyngeal and mandibular teeth were detected, as well as the presence of mucous cells and the formation of longitudinal oesophageal and intestinal folds (by 5-6 dph), which were directly linked to the ability of larvae to start exogenous feeding. The secretion of goblet cells could facilitate food ingestion and digestive regional transition of food particles, and mucous secretions can participate in the protection of the digestive mucosa from proteolytic degradation, and in the prevention of mechanical injuries and bacterial infections (Kapoor et al. 1975, Sarasquete et al. 2001, Zambonino-Infante et al. 2008). The first taste buds consisting of modified epithelial cells appeared on the surface of the buccopharyngeal cavity of C. labrosus larvae at $5 \mathrm{dph}$. These chemosensory structures are important in the selection of the food and play a crucial role in foraging management and food recognition and selective preferences. In the larval development of fishes, the number of taste buds increased with growth, and the differences in number and distribution may increase gustatory efficiency (Kawamura et al. 2003, Falk-Petersen 2005).

The presence of hepatic glycogen and lipid reserves, and the appearance of an intestinal PAS positive brush border (neutral glycoconjugates) were evident early (3-4 dph) and associated with glucidic and lipid metabolic changes, and with digestive processes of absorption and transport of macromolecules through the membranes (Segner et al. 1994, Sarasquete et al. 1995, 2001, Ortiz-Delgado et al. 2003, 2012, Papadakis et al. 2013). The presence of neutral lipids in the anterior intestinal mucosa $(8 \mathrm{dph})$ after the beginning of exogenous feeding has been described in many other larval fish species as an indicator of luminal lipid absorption and storage due to poor lipid metabolism, which improves with larval growth (Govoni et al. 1986, Deplano et al. 1991, Segner et al. 1994, Sarasquete et al. 1995, Ortiz-Delgado et al. 2003, 2012, Papadakis et al. 2013). Pinocytotic invaginations and acidophilic supranuclear vesicles were prominent in the enterocytes of the posterior intestine from $5 \mathrm{dph}$. In many larval fishes these vesicles contained proteins, cathepsin-like enzymes and acid phosphatase (Govoni et al. 1986, Sarasquete et al. 1993a, b, Zambonino-Infante et al. 2008). These vesicles are involved in the pynocytotic uptake of proteins, which are subsequently digested intracellularly. In some teleosts, they are present only until formation of the gastric glands, suggesting a transient mechanism for protein digestion, related to the immaturity of the digestive tract, as well for compensation of a weak or absent extracellular digestion of proteins (Iwai and Tanaka 1968, Stroband and Dabrowski 1981, Watanabe 1982, Govoni et al. 1986, Segner et al. 1994, Sarasquete et al. 1995, Falk-Petersen 2005). In $C$. labrosus larvae, the pinocytotic vesicles were evident until advanced developmental stages (78 dph), suggesting the simultaneous presence of both types of protein digestion (intra- and extracellular). These pinocytotic supranuclear proteic vesicles have been described in the posterior intestine of both larval and adult fishes with stomachs (Albertini-Berhaut 1973, Govoni et al. 1986, Falk-Petersen 2005, ZamboninoInfante et al. 2008). This physiology could be related to a low protein diet and associated with the typical feeding habits of this omnivorous-detritivorous mullet species, which should have lower protein requirements for larval development than many other species with different feeding preferences and higher protein needs (Govoni et al. 1986, Zambonino-Infante et al. 2008, Pittman et al. 2013).

In C. labrosus larvae, eosinophilic zymogen proteic granules (proenzymes) were visible before first feeding (by $3 \mathrm{dph}$ ) within basophilic cytoplasm of pancreocytes, suggesting a genetically programmed, 
rather than dietary-induced, differentiation (Govoni et al. 1986, Falk-Petersen 2005, Zambonino-Infante et al. 2008). The ability of the fish larvae to digest proteins increases with larval development and age, as has been confirmed by several enzymatic and histochemical analyses. Comparative studies of digestive enzymes in many fishes with different nutritional behaviours have demonstrated that amylase activity is greater in herbivorous and omnivorous fish than in carnivorous fish (Establier et al. 1985, Govoni et al. 1986, Walford and Lam 1993, Moyano et al. 1996, Ribeiro et al. 1999, Zambonio-Infante et al. 2008). Mugilidae have very high levels of activity for amylase, trypsin, peptidases and phosphatases from early larval and juvenile stages, as in adult fish (Establier et al. 1985, Ben Khemis et al. 2006, Zouiten et al. 2008). Young mullets would be able to efficiently use diets containing high levels of starch or other similar low-cost amylolytic energetic compounds. The existence of well-developed amylase synthesis capacity may be an interesting feature from the perspective of feed formulation. The utilization of carbohydrates could help to achieve the development of diets with minimized energetic cost as it is an inexpensive source of energy (Ben Khemis et al. 2006, Zouiten et al. 2008, Hamre et al. 2013).

Chelon labrosus juveniles and adults have a long intestine, six pyloric caeca, a well-developed muscular stomach and numerous teeth, suggesting their preferential omnivorous-detritivorous feeding habits (AlbertiniBerhaut 1973, Drake et al. 1984). Well-developed pyloric caeca appeared at the same time as gastric gland differentiation (22-23 dph). Tryptophan-rich proteins, histochemically detected in gastric glands, could be related to pepsinogen synthesis (Sarasquete et al. 1995, 1996, 1998, Zambonino-Infante et al. 2008). The pyloric muscular stomach or typical mullet gizzard (without gastric glands) was discernible around $23 \mathrm{dph}$ and it was well-developed and noticeable at $78 \mathrm{dph}$. It is a specialized pyloric stomach formed by thick, muscular walls used for grinding up food that also aids in digestion of detritus, sediments, waste nutrients and other residues (Albertini-Berhaut 1973, Drake et al. 1984, Brusle 1981b). Together with the gastric glands, the presence of the pyloric caeca could well be, at least partly, related to the faster growth rate detected in C. labrosus between 22 and $54 \mathrm{dph}$. Pyloric caeca facilitate digestion by transport of absorbable nutrients to the bloodstream before passage of the food bolus to the intestine for further breakdown and absorption. Their presence was associated with an increase in the intestinal absorptive area, but was also involved in nutrient lipid absorption, enzymatic secretion and enhancement of food assimilation. Pyloric caeca may also neutralize the acid bolus entering the intestine from the stomach, which is supported by the absence of pyloric caeca in stomachless fishes (Stroband and Dabrowski 1981, Govoni et al. 1986, Falk-Petersen 2005, Zambonino-Infante et al. 2008).

Different organs and cellular structures (endocrine, cardio-respiratory, haematopoietic and others) developed temporal and progressively, but with some species-specific differences associated with a particular time sequence of the main ontogenetic events and parallel functionality (Falk-Petersen 2005). The first thyroid follicle (under the gill arch area) differentiated at the same time as the mouth opened. In the larvae of $C$. labrosus, these follicles proliferated in number, size and functionality (at $23 \mathrm{dph}$ ) more slowly than in other fishes, such as Solea senegalensis and Thunnus thynnus (Ortiz-Delgado et al. 2006, Padros et al. 2011, Yúfera et al. 2014), because these species have a more complex metamorphic process or a much faster growth, which are both thyroid-dependent processes (Yamano 2005). During larval development, and especially during metamorphosis, the follicles and thyroid gland became progressively taller and the colloid showed vacuole-like spaces, which are signs of an active functionality, as detected at histochemical level and reported in other fishes (Ortiz-Delgado et al. 2006). Thyroid gland development has been related to neuro-retinal differentiation and eye pigmentation. Thyroid hormones stimulate gastric gland development and production of pepsinogen and participate in development of skeletal muscle, gill chloride cells and many other functions (Miwa et al. 1992, Tanaka et al. 1995, Yamano 2005). When compared with other organ systems, the gills are formed relatively late in development and gradually displace the skin (Shelbourne 1955) as the site of most exchange activities (respiratory, osmoregulatory and sensory structures). Gill arches without primary filaments, already provided with chloride cells, are only rudimentary in the fish larvae (Sarasquete et al. 1998, 2001, Rombough 2004, Padros et al. 2011, Ortiz-Delgado et al. 2012). From this time on, during the metamorphosis phase, secondary lamellae and a high number of chloride and mucous cells are visible in gill filaments, indicating a major shift of the respiratory function from the skin to the gills (Rombough 2004, Santamaría et al. 2004, FalkPetersen 2005). In the fish gill histological changes are coupled with notochord flexion and onset of development of the caudal fin complex, indicating a change in larval swimming performance, and consequently a greater oxygen demand for swimming activities. During the development and larval growth, the progressive increase of the respiratory surface was noticeable and significant. With age, larvae showed higher branchial functional capability, and the gas exchange across the skin decreased (Rombough 2004, Falk-Petersen 2005, Padrós et al. 2011). The kidney and spleen, with excretory, haematopoietic, haemo-catheretic and immune cell structures, were differentiated with similar developmental and physiological patterns to those reported for many other larval fishes (Tanaka et al. 1995, Padrós and Crespo 1996, Watts et al. 2003, Santamaria et al. 2004, Padros et al. 2011 and others), and they were well- developed and fully functional at the end of the first month of life.

\section{Visual system}

In marine altricial fishes, of the many developmental changes occurring during the early larval stages, two of the most important ontogenetic and physiological events are related to the visual and digestive 
systems, which show parallel functional capabilities (Blaxter 1975, 1986, Hubbs and Blaxter 1986, Huse 1993). In newly hatched larvae, the eye lens showed undifferentiated cells having a spherical distribution. The appearance of the retinal pigment epithelium is considered characteristic of a functional eye (Evans and Browman 2004, Bejarano-Escobar et al. 2014). An early visual functionality was also detected during the endogenous feeding phase of $C$. labrosus, with a precocious appearance of the pigment epithelium (from 2 dph) and the first single cone cell types are beginning to develop in the ONL. There was a functional vision at mouth opening such as that reported in many different altricial fish larvae (Porter and Theilacker 1999, Roo et al. 1999, Kawamura et al. 2003, Peña and Dumas 2007, Ortiz-Delgado et al. 2012, Yúfera et al. 2014). A single pure cone retina may provide for acute visual discrimination, such as the visual detection of prey, but limits vision to relatively high light-intensity conditions (photopic acuity) in surface waters during the day (Blaxter and Staines 1970, Hubbs and Blaxter 1986, Evans and Browman 2004). A single pure cone retina has limited visual acuity and wavelength sensitivity, reducing target contrast and feeding efficiency, which might limit the distribution and feeding habits or range of the larvae in the water column (Hunter 1981, Hubbs and Blaxter 1986, Evans and Browman 2004). The differentiation of the GCL prior to full cone formation indicates a simultaneous development of retinal receptors and the optic tectum, allowing the transmission of nerve impulses when the eyes become functional (Margulies 1997, Evans and Browman 2004). A retinal thickening in the temporal region in the area lateralis was also noticeable in C. labrosus larvae at $6 \mathrm{dph}$, and is indicative of acute vision in dorso-nasal direction. This retinal ontogenetic characteristic, combined with the presence and distribution of the horizontal cells in the area lateralis and throughout the entire retina, can allow movement perception for detecting better fastmoving prey, and thus a more size-selective feeding (Margulies 1997, Kawamura et al. 2003).

The second period of active differentiation in the larval fish retina occurs during the transformation to the juvenile stage, and includes an increase in the amount of cone photoreceptors and the appearance of the first rods, as well as a differential expression of virtual pigments in both types of photoreceptors and development of other retinal cell types (Blaxter and Staines 1970, Evans and Browman 2004, Bejarano-Escobar et al. 2014). The proliferation of rods and the emergence of scotopic vision play an important role in retina development, because it makes the larvae more capable of feeding under low illumination conditions and increases their motion sensitivity, contributing to predator avoidance (Hunter 1981, Margulies 1997, Evans and Browman 2004, Morote et al. 2008). In many different species a mature and physiologically functional retina has been associated with the presence of visual pigments and other neurochemical macromolecules (e.g. opsins, calretinin, parvalbumin and protein kinase C) that are selectively expressed by different retinal cell types (Bejarano-Escobar et al. 2014). In C. labrosus larvae, first rod precursors were differentiated from $16 \mathrm{dph}$, and appeared very early (6-9 dph) in larvae of typical demersal fish species, such as Merluccius merluccius (Ortiz-Delgado et al. 2012). Tuna species developed rods from 17 to 19 dph (Kawamura et al. 2003, Yúfera et al. 2014). Later in development, during the metamorphosis phase, a significant proliferation of rod photoreceptors was detected. It was suggested that improvements in visual capacity were associated with increases in rods and thus higher photo-sensitivity, and also with the development of the lens retractor muscle, which allows the eye to focus on objects at different distances and increases the visual field (Porter and Theilacker 1999, Evans and Browman 2004). Unlike other vertebrates (Bejarano-Escobar et al. 2014), the fish retina continues to grow throughout the life of the animal, showing active sites of cell proliferation and apoptosis, new retinal pigments and neurochemical cell-molecules, as well a renewal of different retinal cell types, which can be de novo synthesized and formed.

Any changes of nutritional and environmental rearing conditions may affect the timing of this ontogenetic developmental sequence to some extent, and should be explored in order to improve larval rearing of this species. According to our results and previous studies in this species, allometric growth patterns, organogenesis, senso-digestive functionality, digestive enzymes and different zootechnical rearing conditions could suggest that the capacity of synthesizing amylase and feeding on vegetal resources seems to be expressed. Thus, young mullets from early larval stages (14-16 dph) can efficiently use diets containing high levels of starch or other similar low-cost amylolytic energetic compounds. These diets could help reduce the cost of aqua-feeds because they are an inexpensive source of energy.

\section{ACKNOWLEDGEMENTS}

This study was funded by the project "Optimización del proceso de maduración y desove del mugílido Chelon labrosus" (Spanish Ministry of Education and European Social Fund). The authors are grateful to IES Els Alfacs (Sant Carles de la Rápita, Tarragona, Spain) for providing fertilized mullet eggs, to Mrs. Isabel Viaña, Mrs. Esmeralda Ramos and Mr. Jose A. Miquel for their excellent technical assistance, and to Dr. Pilar Drake for helping with the statistical analysis. Finally, we would like to thank Dr J.J. Govoni for his invaluable contribution to the revision of this manuscript.

\section{REFERENCES}

Albertini-Berhaut T.J. 1973. Biologie des estades juvénils de Téléostéens Mugilidae, Mugil auratus, Risso 1810, M. capito, Cuvier 1829 et $M$. saliens, Risso 1810. 1. Régime alimentaire. Aquaculture 2: 251-266.

http://dx.doi.org/10.1016/0044-8486(73)90158-0

Arias A.M., Drake P. 1990. Estados juveniles de la ictiofauna de los caños de las salinas de la Bahía de Cádiz. CSIC y Consejería de La Gobernación, Junta de Andalucía (España), 168 pp.

Balon E.K. 1981. Saltatory processes and altricial to precocial forms in the ontogeny of fishes. Am. Zool. 21, 573-596.

Balon E.K. 1986. Types of feeding in the ontogeny of fishes and the life-history model. Environ. Biol. Fish. 16: 11-24. 
http://dx.doi.org/10.1007/BF00005156

Bejarano-Escobar R., Blasco M., Martín-Partido G., et al. 2014 Molecular characterization of cell types in the developing, mature, and regenerating fish retina. Rev. Fish Biol. Fisheries (Reviews) 24: 127-158.

http://dx.doi.org/10.1007/s11160-013-9320-z

Ben Khemis I., Zouiten D., Besbes R., et al. 2006. Larval rearing and weaning of thick lipped grey mullet (Chelon labrosus) in mesocosm with semi-extensive technology. Aquaculture 259: 190-201. http://dx.doi.org/10.1016/j.aquaculture.2006.05.007

Ben Khemis I.B., Gisbert E., Alcaraz C., et al. 2013. Allometric growth patterns and development in larvae and juveniles of thick-lipped grey mullet Chelon labrosus reared in mesocosm conditions. Aquac. Res. 44: 1872-1888.

Besbes R., Besbes B., Ben Khemis I., et al. 2010. Développement et croissance comparés des larves du mullet lippu Chelon labrosus (Mugilidae) élevées en conditions intensives: eau verte et eau claire. Cybium 34: 145-150.

Blaxter J.H.S. 1975. The eye of larval fish. In: Vision in Fishes. In: Ali M.A. (ed.), New Approaches in Research. Plenum Press. New York, pp. 427-443.

Blaxter J.H.S., 1986. Development of sense organs and behaviour of teleost larvae with special reference to feeding and predator avoidance. Trans. Am. Fish. Soc. 115: 98-114.

Blaxter J.H.S., Staines, M. 1970. Pure cone retinae and retinomotor responses in larvae teleosts. J. Mar. Biol. Assoc. U.K., 50: 449-460. http://dx.doi.org/1 0.1017/S0025315400004641

Boglione C., Bertolini B., Russielo M., et al. 1992. Embryonic and larval development of the thick-lipped mullet (Chelon labrosus) under controlled reproduction conditions. Aquaculture 101: 349-359. http://dx.doi.org/10.1016/0044-8486(92)90037-L

Bruslé J. 1981a. Sexuality and biology of reproduction in grey mullets. In: Oren O.H (ed.), Aquaculture of Grey Mullet. Cambridge University Press. Cambridge U.K., pp. 99-159

Bruslé J. 1981b. Food and feeding in grey mullet In: Oren O.H (ed.), Aquaculture of Grey Mullet. Cambridge University Press, Cambridge U.K., pp. 185-218.

Cataudella S., Crosseti D., Massa F., et al. 1988. The propagation of juvenile mullet (Chelon labrosus) in earthern ponds. Aquaculture 68: 321-323. http://dx.doi.org/10.1016/0044-8486(88)90246-3

Crosetti D., Cataudella, S. 1995. The mullets. In: Nash C.E., Novotny A.J (eds). Production of Aquatic Animals (Fishes-C8) World Animal Science. Elsevier. Amsterdam, the Netherlands, pp. 253-268

Deplano M., Diaz R. Connes M. et al. 1991. Appearance of lipidabsorption capacities in larvae of the sea bass, Dicentrarchus labrax during transition to the exotrophic phase. Mar. Biol. 108: 361-371. http://dx.doi.org/10.1007/BF01313645

Dinis M.T., Ribeiro L., Soares F., et al. 1999. A review on the cultivation potential of Solea senegalensis in Spain and Portugal. Aquaculture 176: 27-38. http://dx.doi.org/10.1016/S0044-8486(99)00047-2

Drake P., Arias A., Gallego, L. 1984. Biología de los Mugílidos (Osteichthyes, Mugilidae) en los esteros de las salinas de San Fernando (Cádiz). III. Hábitos alimentarios y su relación con la morfometría del aparato digestivo. Inv. Pesq. 48(2): 337-367.

Eda H., Murashige R., Oozcki Y., et al. 1990. Factors affecting intensive larval rearing of striped mullet, Mugil cephalus. Aquaculture 91: 281-294. http://dx.doi.org/10.1016/0044-8486(90)90194-R

Establier R., Blasco J., Gutiérrez M., et al. 1985. Enzimas en organismos marinos. III. Actividad amilásica en diversos órganos de mugílidos. Inv. Pesq. 49: 255-259.

Evans B.I., Browman H.I. 2004. Variation in the Development of the Fish Retina. Am. Fish. Soc. Symp. 40: 145-166

Falk-Petersen I.B. 2005. Comparative organ differentiation during early life stages of marine fish. Fish Sellfish Immunol. 19: 397-412. http://dx.doi.org/10.1016/j.fsi.2005.03.006

Fuiman L.A.1983. Growth gradients in fish larvae. J Fish Physiol. 23: $117-123$.

Gisbert E., Ortiz-Delgado J.B., Sarasquete, C. 2008. Nutritional cellular biomarlers in early life stages of fish. Histol. Histopathol. 23: $1525-1539$

Govoni J.J., Boehlert G.W., Watanabe Y. 1986. The physiology of digestion in fish larvae. Environ. Biol. Fishes 16: 59-77. http://dx.doi.org/10.1007/BF00005160

Hamre K., Yúfera M., Rønnestad I., et al. 2013 Fish larval nutrition and feed formulation: knowledge gaps and bottlenecks for advances in larval rearing. Rev. Aquacult. 5(Suppl. 1): S26-S58. http://dx.doi.org/10.1111/j.1753-5131.2012.01086.x

Hubbs C., Blaxter J.H.S. 1986. Development of sense organs and behaviour in teleost larvae with special reference to feeding and predation avoidance. Trans. Am. Fish. Soc. 115: 98-114. http://dx.doi.org/10.1577/1548-8659(1986)115<98:NLFCDO> 2.0.CO;2

Hunter J.R. 1981. Feeding ecology and predation of marine fish larvae. In: Lasker R. (ed.), Marine Fish Larvae Morphology, Ecology and Relation to Fisheries. Univ. Washington Press, Seattle pp. 33-79.

Huse I. 1993. First feeding larval sensory perception and behavioural programming: Implications for system and procedures in culture. In: Walther, B.T., Fyhn, H.J (eds), Physiology and Biochemical Aspects of Fish Development. Bergen. University Norway, Bergen, pp. 146-152.

Iwai T., Tanaka M. 1968. The comparative study of the digestive tract of teleost larvae. III. Epithelial cells in the posterior gut of halfbeak larvae. Bull. Jpn. Soc. Sci. Fish., 43: 44-48. http://dx.doi.org/10.2331/suisan.34.44

Kapoor B.G., Smith H., Verighina I.A. 1975. The alimentary canal and digestion in teleosts. Adv. Mar. Biol. 13: 109-239. http://dx.doi.org/10.1016/S0065-2881(08)60281-3

Kawamura G., Masuma S., Tezuka N., et al. 2003. Morphogenesis in sense organs in the bluefin tuna Thunnus orientalis. In: Browman H.J., Skiftesvik A.B. (eds), The Big Fish Bang. Proceedings of the 26th annual larval fish conference), pp. 123-135.

Kiernan J.A. 1999. Histological and Histochemical Methods. Theory and Practice, 3rd ed. Oxford University Press Inc, $502 \mathrm{pp}$.

Löffler J., Ott A., Ahnelt, H., et al. 2008. Early development of the skull of Sander lucioperca (L.) (Teleostei: Percidae) relating to growth and mortality. J. Fish Biol. 72: 233-258. http://dx.doi.org/10.1111/j.1095-8649.2007.01699.x

Margulies D. 1997. Development of the visual system and inferred performance capabilities of larval and early juvenile scombrids. Mar. Fresh. Behav. Physiol. 30: 75-98. http://dx.doi.org/10.1080/10236249709379018

Miwa S., Yamano K., Inui Y. 1992. Thyroid hormone stimulates gastric development in flounder larvae during metamorphosis. J. Exp. Zool. 261: 424-430. http://dx.doi.org/10.1002/jez.1402610409

Morote E., Olivar P., Pankhurst P.M., et al. 2008. Trophic ecology of blue tuna Auxis rockei larvae and ontogeny of feeding-related organs. Mar. Ecol. Prog Ser. 353: 243-254. http://dx.doi.org/10.3354/meps07206

Moyano F.J., Diaz M., Alarcon F.J., et al. 1996. Characterization of digestive enzyme activity during larval development of gilthead seabream, Sparus aurata L. Fish Physiol. Biochem. 15(2): $121-130$ http://dx.doi.org/10.1007/BF01875591

Ortiz-Delgado J.B., Darias M.J., Cañavate J.P, et al. 2003. Organogenesis of the digestive tract in the white seabream, Diplodus sargus. Histological and histochemical approaches. Histol. Histopathol. 18: 1141-1154.

Ortiz-Delgado J.B., Ruane N.M., Poucão-Ferreira P., et al. 2006. Thyroid gland development in Senegalese sole (Solea senegalensis Kaup 1858) during early life stages: a histochemical and immunohistochemical approach. Aquaculture 260: 346-356.

Ortiz-Delgado J.B., Iglesias J., Sánchez F.J., et al. 2012. A morphohistological and histochemical study of hatchery-reared European hake, Merluccius merluccius (Linnaeus, 1758), during the lecitho-exotrophic larval phase. Sci. Mar.76: 259-271. http://dx.doi.org/10.3989/scimar.03424.03C

Ott A., Loffler J., Ahnelt, H., et al. 2012. Early development of the postcranial skeleton of the pikeperch, Sander lucioperca (Teleostei: Percidae) relating to developmental stages and growth. J. Morph. 273: 894-908. http://dx.doi.org/10.1002/jmor.20029

Padrós F., Crespo S. 1996. Ontogeny of the lymphoid organs in the turbot, Scophthalmus maximus: a light and electron microscope study. Aquaculture 144: 1-16. http://dx.doi.org/10.1016/S0044-8486(96)01326-9

Padrós F., Villalta M., Gisbert E., et al. 2011. Morphological and histological study of larval development of the Senegal sole, Solea senegalensis: an integrative study. J. Fish Biol. 79: 3-32. http://dx.doi.org/10.1111/j.1095-8649.2011.02942.x 
Papadakis I.E., Kentouri M., Divanach P., et al. 2013. Ontogeny of the digestive system of meagre, Argirosomus regius reared in a mesocosm, and quantitative changes of lipids in the liver from hatching to juvenile. Aquaculture 338-391: 76-88.

Pearse A.G.E. 1985. Histochemistry: Theoretical and applied. 4th edition. Churchill, Livingstone, Edinburg, 1055 pp.

Peña R., Dumas S. 2007. Development of the retina in spotted sand bass Paralabrax maculatofasciatus (Percoidei: Serranidae) larvae under culture conditions. Cienc. Mar. 33(3): 293-300.

Pittman K., Yúfera, M., Pavlidis, M., et al., 2013. Fantastically plastic: fish larvae equipped for a new world. Rev. Aquacult. 5(Suppl. 1): S224-S267 http://dx.doi.org/10.1111/raq.12034

Porter S.M., Theilacker G.H. 1999. The development of the digestive tract and eye in larval walleye Pollock, Theragra chalcogramma. Fish Bull. 97: 722-729.

Ribeiro L., Zambonino-Infante J.L., Cahu C., et al. 1999. Development of digestive enzymes in larvae of Solea senegalensis Kaup 1858. Aquaculture 179: 465-473. http://dx.doi.org/10.1016/S0044-8486(99)00180-5

Rombough P.J. 2004. Gas exchange, ionoregulation and the functional development of the teleost gill. Am. Fish. Soc. Symp. 40: 47-83.

Rønnestad I., Yúfera M., Ueberschär B., et al. 2013. Feeding behaviour and digestive physiology in larval fish: current knowledge, and gaps and bottlenecks in research. Rev. Aquacult. 5(Suppl. 1): S59-S98. http://dx.doi.org/10.1111/raq.12010

Roo F.J., Socorro J., Izquierdo M.S., et al. 1999. Development of red porgy Pagrus pagrus visual system in relation with changes in the digestive tract and larval feeding habits. Aquaculture 179: 499-512. http://dx.doi.org/10.1016/S0044-8486(99)00183-0

Santamaría C.A., Marín-Mateo M., Traveset R., et al. 2004. Organogenesis in larval common Dentex dentex L. (Sparidae): histological and histochemical aspects. Aquaculture 237: 207-228. http://dx.doi.org/10.1016/j.aquaculture.2004.03.020

Sarasquete C., Gutiérrez M. 2005. New Tetrachromic VOF Stain (Type III-G.S) For Normal and Pathological Fish Tissues. Eur. J. Histochem. 49(2): 105-114.

Sarasquete C., Polo A., Pascual E. et al. 1993a. Histochemistry of proteins, lipids and carbohydrates in the yolk constituents of oocytes, eggs and larvae of Sparus aurata L. In: Walther B.T., Fyhn H.J. (eds), Physiological and biochemical aspects of fish development. University of Bergen, Bergen, pp. 309-314.

Sarasquete C., Polo A., González de Canales M.L. 1993b. A histochemical and immunohistochemical study of digestive enzymes and hormones during the larval development of the seabream, Sparus aurata. Histochem. J. 25: 430-437. http://dx.doi.org/10.1007/BF00157807

Sarasquete C., Polo A., Yúfera, M 1995. Histology and histochemistry of the development of the digestive system of larval gilthead seabream, Sparus aurata L. Aquaculture 130: 79-92. http://dx.doi.org/10.1016/0044-8486(94)00175-N

Sarasquete C., González de Canales M.L., Arellano J.M., et al 1996. Histochemical aspects of the yolk-sac and digestive tract of the Senegal sole, Solea senegalensis. Histol. Histopathol. 11: $881-888$.

Sarasquete C., González de Canales M.L., Arellano J.M., et al.
1998. Histochemical study of skin and gills of Senegal sole, Solea senegalensis larvae and adults. Histol. Histopathol. 13: 727-735

Sarasquete C., Gisbert E., Ribeiro L., et al. 2001. Glycoconjugates in epidermal, branchial and digestive mucous cells and gastric glands of gilthead seabream, Sparus aurata, Senegal sole, Solea senegalensis and Siberian sturgeon, Acipenser baeri. Eur. J. Histochem. 45: 267-278

Segner H., Storch V., Reinecke M., et al. 1994. The development of functional digestive and metabolic organs in turbot, Scophthalmus maximus. Mar. Biol. 119: 35-39 http://dx.doi.org/10.1007/BF00347544

Shelbourne J.E. 1955. Significance of the subdermal space in pelagic fish embryos and larvae. Nature 176: 743-744. http://dx.doi.org/10.1038/176743a0

Stroband H.W.J., Dabrowski, K.R. 1981. Morphological and physiological aspects of the digestive system and feeding in freshwater fish larvae. In: Fontaine, M (ed.), Nutrition des Poissons. Edition de Centre National de la Researche Scientifique, Paris, France, pp. 353-376.

Tanaka M., Tanangonan J.B., Tawawa M., et al. 1995. Development of the pituitary gland, thyroid and interrenal glands and applications of endocrinology to the improved rearing of marine fish larvae. Aquaculture 135: 111-126. http://dx.doi.org/10.1016/0044-8486(95)01019-X

Walford J., Lam T.J. 1993. Development of digestive tract and proteolytic enzyme activity in seabass (Lates calcarifer) larvae and juveniles. Aquaculture 109: 187-205. http://dx.doi.org/10.1016/0044-8486(93)90215-K

Watanabe Y. 1982. Ultrastructure of epithelial cells of the anteromedian intestine and the rectum in larval and juvenile teleosts. Bull. Fac. Fish. Hokkaido University 33: 217-228.

Watts M., Kato K., Munday B.L., et al. 2003. Ontogeny of immune system organs in northern bluefin tuna (Thunnus orientalis, Temmick and Schlegel 1844). Aquac. Res. 34: 13-21. http://dx.doi.org/10.1046/j.1365-2109.2003.00779.x

Yamano K. 2005. The Role of Thyroid Hormone in Fish Development with reference to Aquaculture. Review JARQ 39(3): 161-168. http://dx.doi.org/10.6090/jarq.39.161

Yúfera M., Arias A.M. 2010. Traditional polyculture in "esteros" in the Bay of Cádiz (Spain). Hopes and expectancies for the prevalence of a unique activity in Europe. Aquac. Eur. 35(3): 22-25.

Yúfera M., Ortiz-Delgado J.B., Hoffman T., et al. 2014. Organogenesis of digestive system, visual system and other structures in Atlantic bluefin tuna (Thunnus thynnus) larvae reared in mesocosm system. Aquaculture 426-427: 126-137. http://dx.doi.org/10.1016/j.aquaculture.2014.01.031

Zambonino-Infante J.L., Gisbert E., Sarasquete C., et al., 2008. Ontogeny and physiology of the digestive system of marine fish larvae. In: Cyrino, JEO, Bureau, D., and Kapoor, B.G. (eds), Feeding and Digestive Functions of Fish. Science Publishers, Inc, Enfield (NH), Jersey, Plymouth, pp. 281-348. http://dx.doi.org/10.1201/b10749-8

Zouiten D., Ben Khemis I., Besbes R., et al. 2008. Ontogeny of the digestive tract of thick lipped grey mullet (Chelon labrosus) larvae reared in mesocosms. Aquaculture 279: 166-172. http://dx.doi.org/10.1016/j.aquaculture.2008.03.039 